\title{
Article \\ A Comprehensive Study of the Genus Sanguisorba (Rosaceae) Based on the Floral Micromorphology, Palynology, and Plastome Analysis
}

\author{
Inkyu Park $\left.{ }^{+} \mathbb{(}\right)$, Junho Song $+\left(\mathbb{D}\right.$, Sungyu Yang, Goya Choi $\mathbb{D}^{-}$and Byeongcheol Moon * \\ Herbal Medicine Resources Research Center, Korea Institute of Oriental Medicine, Naju 58245, Korea; \\ pik6885@kiom.re.kr (I.P.); songjh@kiom.re.kr (J.S.); sgyang81@kiom.re.kr (S.Y.); serparas@kiom.re.kr (G.C.) \\ * Correspondence: bcmoon@kiom.re.kr; Tel.: +82-61-338-7100 \\ + These authors contributed equally to this work.
}

check for

updates

Citation: Park, I.; Song, J.; Yang, S.; Choi, G.; Moon, B. A Comprehensive Study of the Genus Sanguisorba (Rosaceae) Based on the Floral Micromorphology, Palynology, and Plastome Analysis. Genes 2021, 12, 1764. https://doi.org/10.3390/ genes12111764

Academic Editor: Jacqueline Batley

Received: 11 August 2021

Accepted: 3 November 2021

Published: 5 November 2021

Publisher's Note: MDPI stays neutral with regard to jurisdictional claims in published maps and institutional affiliations.

Copyright: (c) 2021 by the authors. Licensee MDPI, Basel, Switzerland. This article is an open access article distributed under the terms and conditions of the Creative Commons Attribution (CC BY) license (https:// creativecommons.org/licenses/by/ $4.0 /)$.

\begin{abstract}
Sanguisorba, commonly known as burnet, is a genus in the family Rosaceae native to the temperate regions of the Northern hemisphere. Five of its thirty species are distributed in Korea: Sanguisorba officinalis, S. stipulata, S. hakusanensis, S. longifolia, and S. tenuifolia. S. officinalis has been designated as a medicinal remedy in the Chinese and Korean Herbal Pharmacopeias. Despite being a valuable medicinal resource, the morphological and genomic information, as well as the genetic characteristics of Sanguisorba, are still elusive. Therefore, we carried out the first comprehensive study on the floral micromorphology, palynology, and complete chloroplast (cp) genome of the Sanguisorba species. The outer sepal waxes and hypanthium characters showed diagnostic value, despite a similar floral micromorphology across different species. All the studied Sanguisorba pollen were small to medium, oblate to prolate-spheroidal, and their exine ornamentation was microechinate. The orbicules, which are possibly synapomorphic, were consistently absent in this genus. Additionally, the cp genomes of S. officinalis, S. stipulata, and S. hakusanensis have been completely sequenced. The comparative analysis of the reported Sanguisorba cp genomes revealed local divergence regions. The nucleotide diversity of $t r n H-p s b A$ and $r p s 2-r p o C 2$, referred to as hotspot regions, revealed the highest pi values in six Sanguisorba. The $n d h G$ indicated positive selection pressures as a species-specific variation in S. filiformis. The S. stipulata and S. tenuifolia species had $p s b K$ genes at the selected pressures. We developed new DNA barcodes that distinguish the typical S. officinalis and S. officinalis var. longifolia, important herbal medicinal plants, from other similar Sanguisorba species with speciesspecific distinctive markers. The phylogenetic trees showed the positions of the reported Sanguisorba species; S. officinalis, S. tenuifolia, and S. stipulata showed the nearest genetic distance. The results of our comprehensive study on micromorphology, pollen chemistry, cp genome analysis, and the development of species identification markers can provide valuable information for future studies on S. officinalis, including those highlighting it as an important medicinal resource.
\end{abstract}

Keywords: Sanguisorba; micromorphology; pollen; plastid genome; DNA barcode; phylogenic analysis

\section{Introduction}

The genus Sanguisorba L. (subtribe Sanguisorbinae, tribe Sanguisorbeae, subfamily Rosoideae, family Rosaceae), commonly known as burnet, consists of 10-33 species that are widely distributed in the Northern hemisphere [1-5]. Members of this genus are perennial herbs, with odd-pinnate, stipulate leaves, and densely capitate or spicate inflorescences with tetramerous, apetalous, and penicillate stigmatic flowers and dry achene fruits [4-8].

In East Asia, seven species of Sanguisorba have been described in China [4] and Japan [7], and six species in Korea [8]. Three species, namely Sanguisorba officinalis L., S. stipulata Raf., and S. tenuifolia Fisch. ex Link, are extensively distributed across these three countries. Moreover, the dried roots of S. officinalis and S. officinalis var. longifolia (Bertol.) 
T.T. Yu and C.L. Li are used together in herbal medicine, known as the Sanguisorbae Radix, and have been designated in the Chinese and Korean herbal pharmacopeias. In addition, S. officinalis is also well-known for its medicinal properties in Europe. [9-12]. Moreover, S. officinalis is traditionally known for its anti-allergic, anti-asthmatic, anti-inflammatory, antioxidant, antibacterial, anticancer, antiviral, and hemostatic effects [12-16]. However, identifying Sanguisorba species is challenging because of the extra-morphological similarity and sympatric distribution of the authentic medicinal resource, S. officinalis, and its close relatives. Thus, it is necessary to conduct comprehensive studies and integrative taxonomy to gain deeper knowledge about their biological properties.

The most recent morphological studies on Sanguisorba have primarily focused on selected characteristics and their evolution, including pollen $[17,18]$ and floral morphogenesis [19]. However, comprehensive and integrative species-based analyses of the micromorphological, palynological, and molecular characteristics have not been performed to date.

The floral micromorphological characteristics observed using scanning electron microscopy (SEM) are useful taxonomic markers at various taxonomic levels and groups. They include the sepal surface of Lathyrus (Fabaceae) [20], the petal surface of the tribe Sorbarieae [21] and Spiraeeae (Rosaceae) [22], and the gynoecium of the genus Arnebia (Boraginaceae) [23]. The comparative floral morphology of the three Sanguisorba taxa has been studied [19]. However, the study focused on floral morphogenesis and did not include S. stipulata or the characteristics of the sepal cuticular surfaces.

Palynological characteristics have also been proven to be useful for systematic implications [17,18,24-27] and taxonomic delimitation [27-30] of various groups in Rosaceae. In particular, the orbicules, the small sporopollenin particles on the inner locule walls, have proven to be a taxonomically and systematically useful palynological characteristic within Rosaceae [31-33]. Although pollen morphology of Sanguisorba has been studied by Chung et al. [17] and Lee et al. [18], the critical-point drying (CPD) method, which negates the side effects of the acetolysis method, such as distortion of shape, has not been investigated. Moreover, the orbicules of Sanguisorba have not yet been studied.

The chloroplast (cp) is one of the most important organs in plants and functions as an essential organelle for photosynthesis, starch and fatty acid biosynthesis, and carbon fixation [34-36]. Genome analysis using cp, which is quick and easy to obtain, is inexpensive; it is an essential strategy in plant studies, particularly in taxonomy, plant identification, and evolutionary studies [34-36]. In general, angiosperms have 110-130 genes, with up to 80 protein-coding genes, 30 transfer RNA (tRNA), and 4 ribosomal RNA (rRNA) genes [34]. The cp genome has a highly conserved structure and gene content, as well as low variance compared to the nuclear and mitochondrial genomes. However, changes in the cp genome size lead to gains and losses in genes, IR expansion and contraction, and structural rearrangements [34-36]. The cp genomes provide useful information through comparative analysis at the family and species levels or designated comparison groups to characterize gene rearrangements, including expansion or contraction of IR regions, gene content, and gene duplication or loss. Furthermore, it enables the analysis and utilization of genetic variations due to insertions/deletions (indels), single sequence repeats (SSRs), and single nucleotide polymorphisms (SNPs). These genetic mutations can be used for species identification, classification, and evolutionary studies [37-39]. The remarkable reproducibility of methods based on these genetic mutation-based markers facilitated the authentication and quality control of herbal medicines [39-41]. Within the Sanguisorbeae tribe, several cp genomes have been reported for S. tenuifolia, S. officinalis, S. sitchensis, S. filiformis, and Bencomia exstipulata [42,43]. Despite being a valuable plant, there is very little genomic information available. Therefore, it is necessary to study the genome of Sanguisorba.

In the present study, four species of Sanguisorba, namely S. hakusanensis, S. officinalis, S. stipulata, and S. tenuifolia, were subjected to micromorphological and palynological analyses, and cp genomes of three species, S. hakusanensis, S. officinalis, and S. stipulata, were sequenced for comprehensive studies. This study aimed to (1) document and illustrate the 
floral micromorphology and palynology of the representative taxa using microscopy techniques; (2) characterize Sanguisorba cp genomes and identify genetically variable regions by comparing their global structures, (3) develop novel DNA barcodes for authenticating the species used in herbal medicines, and (4) understand the evolutionary relationships within the tribe Sanguisorbeae.

\section{Results}

\subsection{Floral Micromorphological Characteristics of Sanguisorba}

The floral epidermal micromorphological characteristics (sepal, gynoecium, and androecium) are summarized in Table 1, and representative micrographs are shown in Figures 1 and 2. The outer sepals of all the studied Sanguisorba species were smooth (Figure 1A-D), whereas those of only Sanguisorba hakusanensis were densely covered with platelet epicuticular waxes (Figure 1A). The inner sepal epidermis of all the studied species was similar; its cells were regularly arranged with straight to curved anticlinal walls and slightly convex with striated periclinal cell walls (cuticular folds) (Figure 2). The gynoecium was unicarpellate with a disk-like structure and comprised a unilocular ovary surrounded by a perigynous hypanthium. The shape of the hypanthium was ellipsoid in S. hakusanensis (Figure 1I) and S. officinalis (Figure 1J), and globose in S. stipulata (Figure 1K) and S. tenuifolia (Figure $1 \mathrm{~L}$ ). The disk-like structure, located on top of the hypanthium, was reduced in thickness. On the surface of the hypanthium, the non-glandular unicellular trichomes were sparse to moderate on the basal and ventral parts of S. hakusanensis (Figure 1I) and the upper part of S. officinalis (Figure 1J) and S. tenuifolia (Figure 1L), while they were glabrous on the surface of S. stipulata (Figure 1K). All the studied Sanguisorba species had fimbriate (penicillate, brush-like) stigma; however, the apex of the fimbriae was blunt in S. hakusanensis (Figure 1M) and S. officinalis (Figure 1N), and acute in S. stipulata (Figure 1O) and S. tenuifolia (Figure 1P). The style and stigma cell surface patterns were observed in all the studied species. S. hakusanensis had the longest filament $(6-10 \mathrm{~mm})$ with compressed dilation in the upper part (Figure 2A), whereas S. officinalis had the shortest (1-3 mm) with a filiform shape (Figure 2B). S. stipulata and S. tenuifolia had moderate filament lengths $(5-8 \mathrm{~mm})$ with compressed dilation in the upper part (Figure 2C,D).

\subsection{Palynological Characteristics of Sanguisorba}

The palynological characteristics (pollen and orbicule) are summarized in Table 1, and representative micrographs are shown in Figure 3. The pollen grains were monads, and their size varied from small to medium $(\mathrm{P}=14.9-27.9 \mu \mathrm{m}, \mathrm{E}=13.8-25.8 \mu \mathrm{m}$; Table 1$)$. S. tenuifolia had the largest pollen grains $(\mathrm{P}=25.0 \pm 1.28 \mu \mathrm{m}, \mathrm{E}=23.5 \pm 1.56 \mu \mathrm{m})$, while S. officinalis $(\mathrm{P}=16.3 \pm 0.85 \mu \mathrm{m}, \mathrm{E}=15.5 \pm 1.15 \mu \mathrm{m})$ had the smallest pollen grains (Table 1). The outline of the pollen grains was mostly circular in polar view (Figure 3A-D). In the equatorial view, pollen grain shapes ranged from oblate-spheroidal to prolatespheroidal $(\mathrm{P} / \mathrm{E}=0.95-1.22$; Figure $3 \mathrm{E}-\mathrm{H})$. Only S. hakusanensis had tricolporate pollen grains (Figure 3A), whereas other species had hexacolporate apertures (Figure 3B-D). The mean value of the colpus ranged from $5.85 \mu \mathrm{m}$ (S. officinalis) to $8.72 \mu \mathrm{m}$ (S. tenuifolia), and that of mesocolpus width ranged from $6.02 \mu \mathrm{m}$ (S. officinalis) to $11.3 \mu \mathrm{m}$ (S. hakusanensis) (Table 1). Three species of $\mathrm{C} / \mathrm{M}$ ratio were $0.9-1.0$, indicating that the widths of both the margins of each colpus and mesocolpus were nearly equal. However, the $\mathrm{C} / \mathrm{M}$ ratio of S. hakusanensis was 0.6, indicating a wider mesocolpus than the colpus. A microechinate exine ornamentation was observed in all the studied species (Figure 3I-L). The orbicules were absent in all the species studied (Figure $3 \mathrm{M}-\mathrm{P}$ ). The $\mathrm{P}$ and $\mathrm{E}$ values of $S$. officinalis were lower, and their 25th and 75th percentiles did not overlap with those of the other three species (Figure $4 \mathrm{~A}, \mathrm{~B}$ ), whereas those of $\mathrm{P} / \mathrm{E}$ overlapped (Figure $4 \mathrm{C}$ ). The $\mathrm{C}$ value of $S$. tenuifolia was higher than that of the other species (Figure 3D). The 25th and 75th percentiles of the $\mathrm{M}$ and $\mathrm{C} / \mathrm{M}$ values of $\mathrm{S}$. hakusanensis did not overlap with those of the other three species (Figure 4E,F). 
Table 1. The floral micromorphological and palynological characteristics of the selected species from Sanguisorba.

\begin{tabular}{|c|c|c|c|c|}
\hline Species & S. hakusanensis & S. officinalis & S. stipulata & S. tenuifolia \\
\hline \multicolumn{5}{|c|}{ Floral characteristics } \\
\hline Outer sepal cell surface & Smooth & Smooth & Smooth & Smooth \\
\hline Outer sepal waxes & Platelets & Absent & Absent & Absent \\
\hline Inner sepal cell surface & Striation & Striation & Striation & Striation \\
\hline Filament length & $6-10 \mathrm{~mm}$ & $1-3 \mathrm{~mm}$ & $5-7 \mathrm{~mm}$ & $6-8 \mathrm{~mm}$ \\
\hline Filament shape & $\begin{array}{c}\text { Compressed-dilated in the } \\
\text { upper part }\end{array}$ & Filiform & $\begin{array}{c}\text { Compressed-dilated in the } \\
\text { upper part }\end{array}$ & $\begin{array}{c}\text { Compressed-dilated in the } \\
\text { upper part }\end{array}$ \\
\hline Hypanthium shape & Ellipsoid & Ellipsoid & Globose & Globose \\
\hline Disk-like structure * & Moderate & Thickened & Moderate & Reduced \\
\hline Hypanthium cell surface & Smooth & Smooth & Smooth & Smooth \\
\hline Hypanthium trichomes & Basal and ventral suture & Upper part & Absent & Upper part \\
\hline Style length & $2-3 \mathrm{~mm}$ & $0.5-1 \mathrm{~mm}$ & $1-2 \mathrm{~mm}$ & $1-2 \mathrm{~mm}$ \\
\hline Style surface & Striation & Striation & Striation & Striation \\
\hline Stigma shape & $\begin{array}{l}\text { Fimbriate with blunted } \\
\text { apex }\end{array}$ & $\begin{array}{l}\text { Fimbriate with blunted } \\
\text { apex }\end{array}$ & Fimbriate with acute apex & Fimbriate with acute apex \\
\hline Stigma surface & Striation & Striation & Striation & Striation \\
\hline & & Palynological characteristics & & \\
\hline Aperture shape & Tricolporate & Hexacolporate & Hexacolporate & Hexacolporate \\
\hline Polar axis $(\mathrm{P})$ & $23.6 \pm 1.5$ & $16.3 \pm 0.8$ & $21.6 \pm 1.2$ & $25.0 \pm 1.3$ \\
\hline Equatorial diameter $(\mathrm{E})$ & $21.0 \pm 1.3$ & $15.5 \pm 1.1$ & $19.6 \pm 0.9$ & $23.5 \pm 1.6$ \\
\hline $\mathrm{P} / \mathrm{E}$ ratio & $1.1 \pm 0.1$ & $1.1 \pm 0.1$ & $1.1 \pm 0.1$ & $1.1 \pm 0.1$ \\
\hline Shape & Prolate-spheroidal & Prolate-spheroidal & Prolate-spheroidal & Prolate-spheroidal \\
\hline Colpus width (C) & $6.7 \pm 1.0$ & $5.8 \pm 0.7$ & $7.3 \pm 0.9$ & $8.7 \pm 0.9$ \\
\hline Mesocolpus width (M) & $11.3 \pm 1.3$ & $6.0 \pm 0.6$ & $7.1 \pm 0.9$ & $9.4 \pm 1.2$ \\
\hline $\mathrm{C} / \mathrm{M}$ ratio & $0.6 \pm 0.1$ & $1.0 \pm 0.2$ & $1.0 \pm 0.2$ & $0.9 \pm 0.1$ \\
\hline Exine ornamentation & Microechinate & Microechinate & Microechinate & Microechinate \\
\hline Orbicule & Absent & Absent & Absent & Absent \\
\hline
\end{tabular}

* Disk-like structure located on top of the hypanthium.

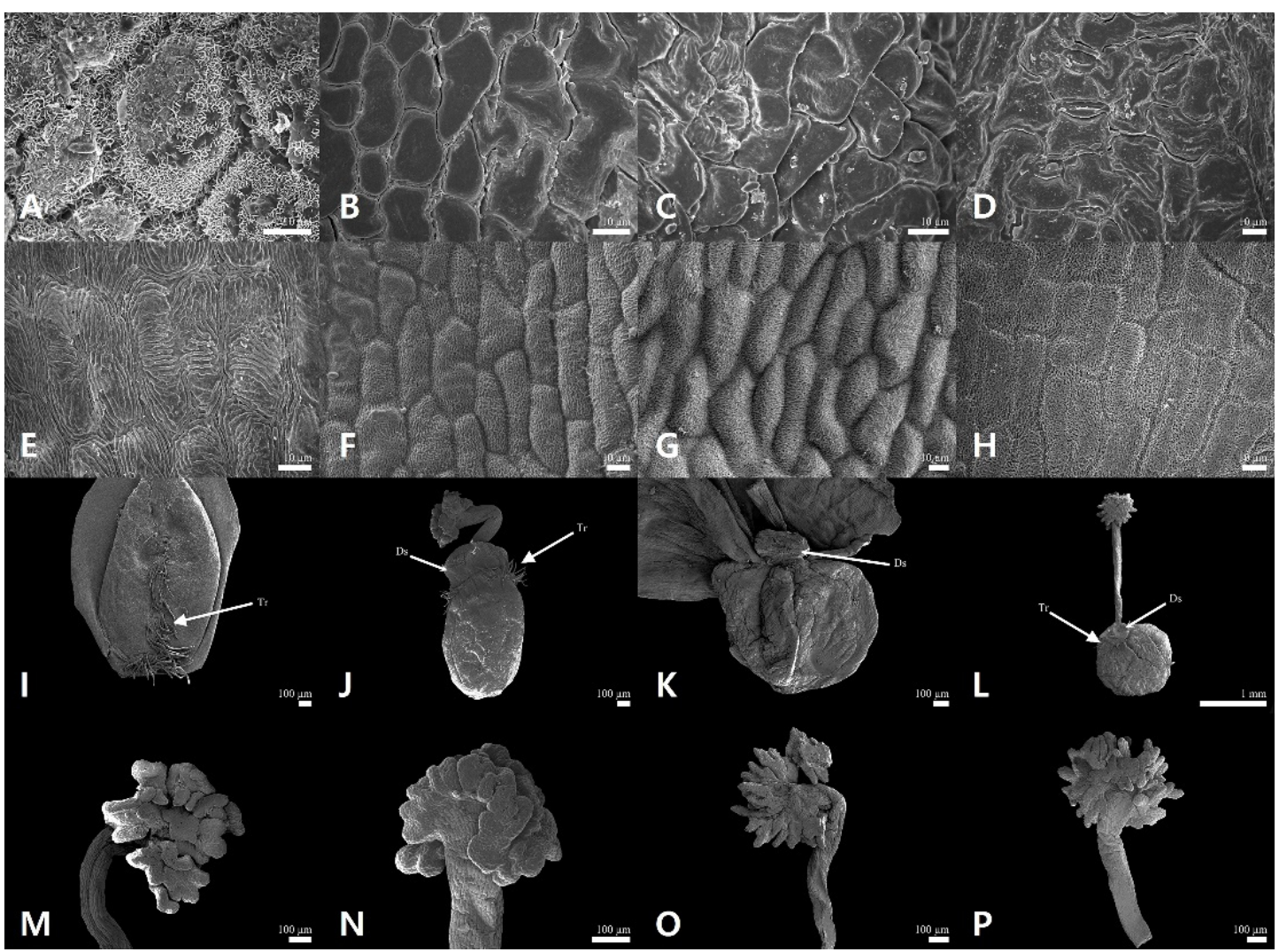

Figure 1. The sepal and gynoecium micromorphological characteristics of Sanguisorba species. (A,E,I,M) S. hakusanensis, $(\mathbf{B}, \mathbf{F}, \mathbf{J}, \mathbf{N})$ S. officinalis, (C,G,K,O) S. stipulata, (D,H,L,P) S. tenuifolia, (A-D) Outer sepal, (E-H) Inner sepal, (I-L) Hypanthium and gynoecium, (M-P) Stigma. DS, Disk-like structure; Tr, Trichome. 


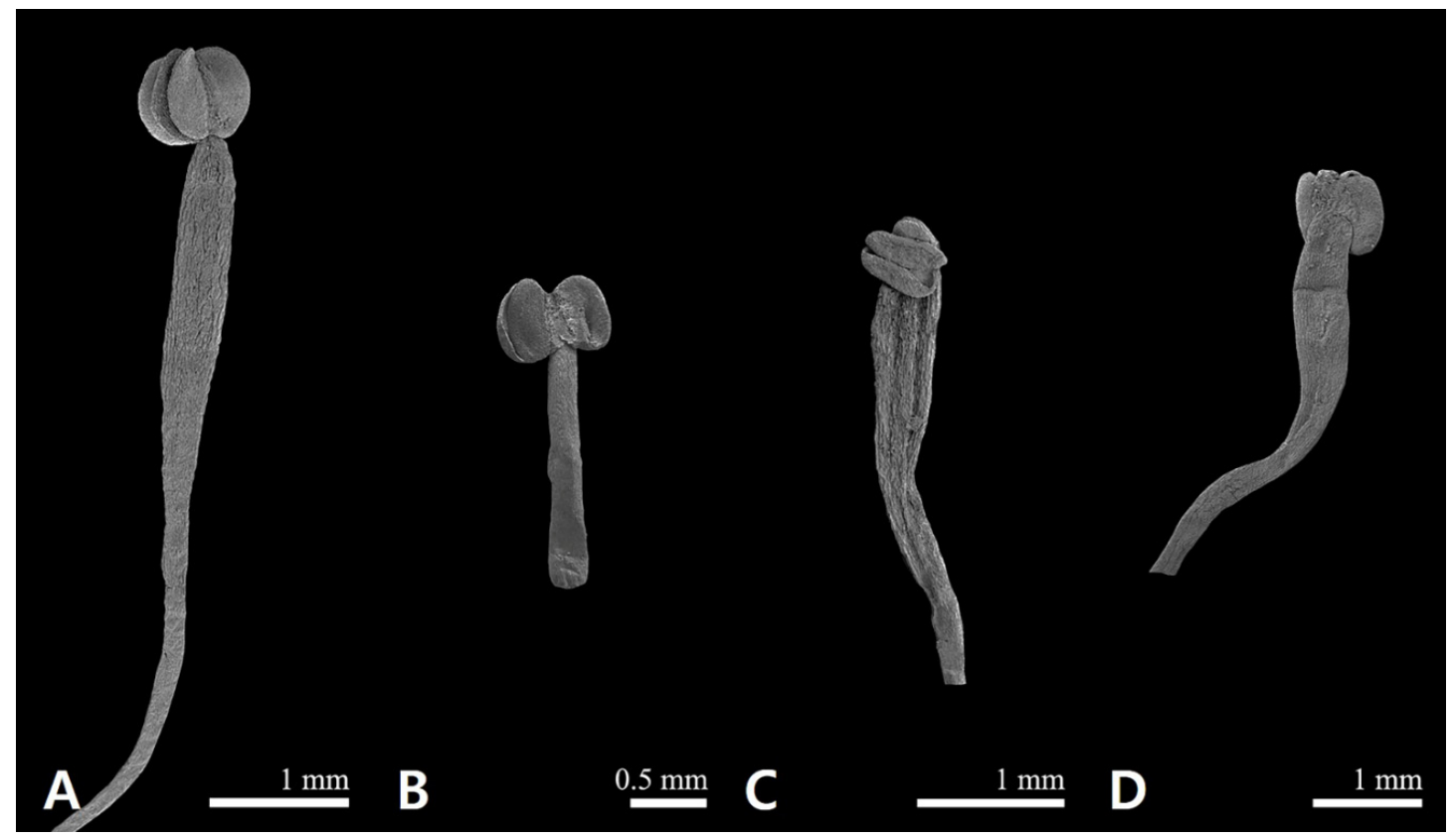

Figure 2. The androecium micromorphological characteristic of Sanguisorba species. (A) S. hakusanensis, (B) S. officinalis, (C) S. stipulata, and (D) S. tenuifolia.

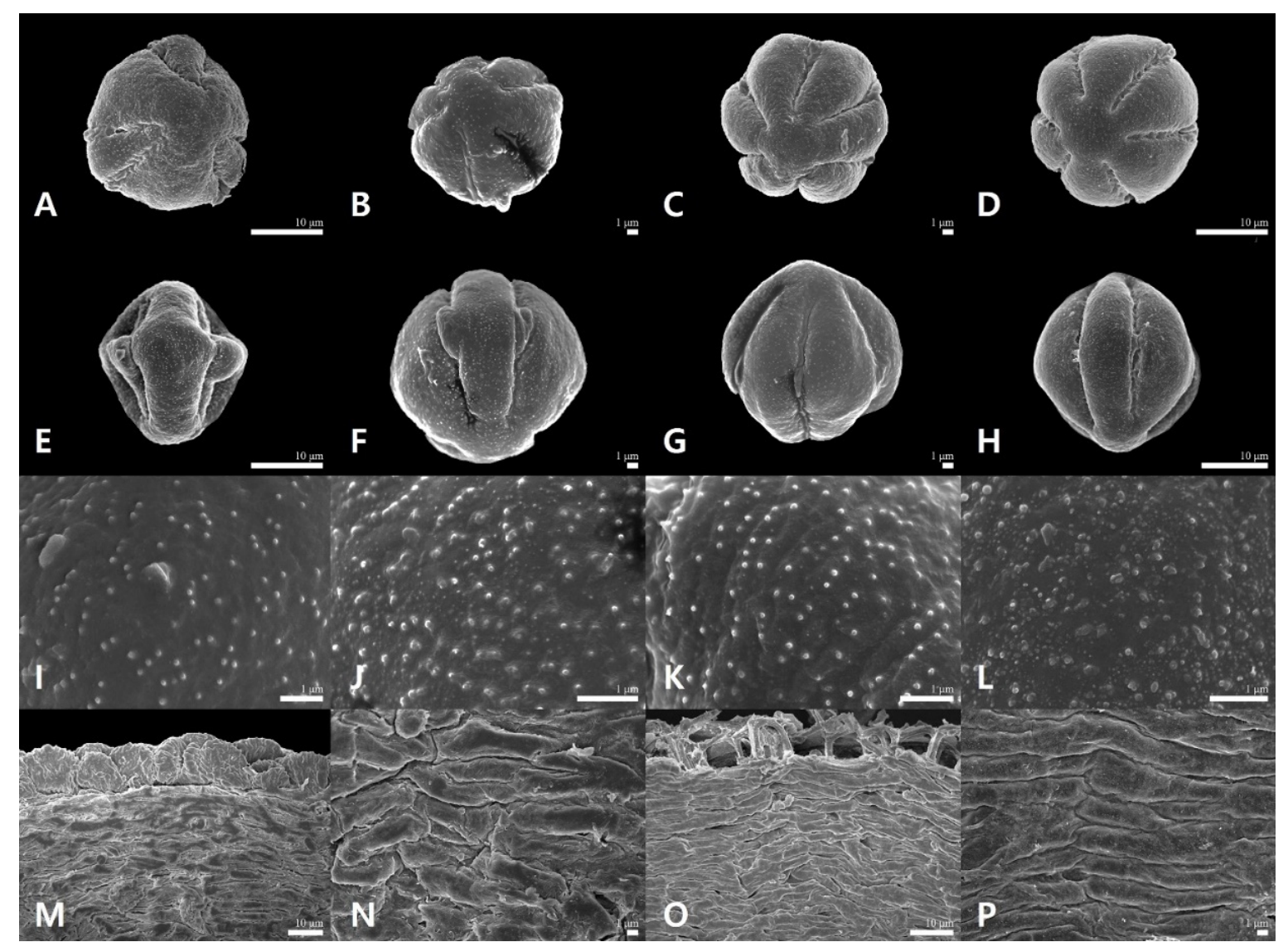

Figure 3. The palynological characteristic of Sanguisorba species. (A,E,I,M) S. hakusanensis, (B,F,J,N) S. officinalis, (C,G,K,O) S. stipulata, (D,H,L,P) S. tenuifolia, (A-D) Polar view, (E-H) Equatorial view, (I-L) Exine ornamentation, (M-P) Inner locule wall. 


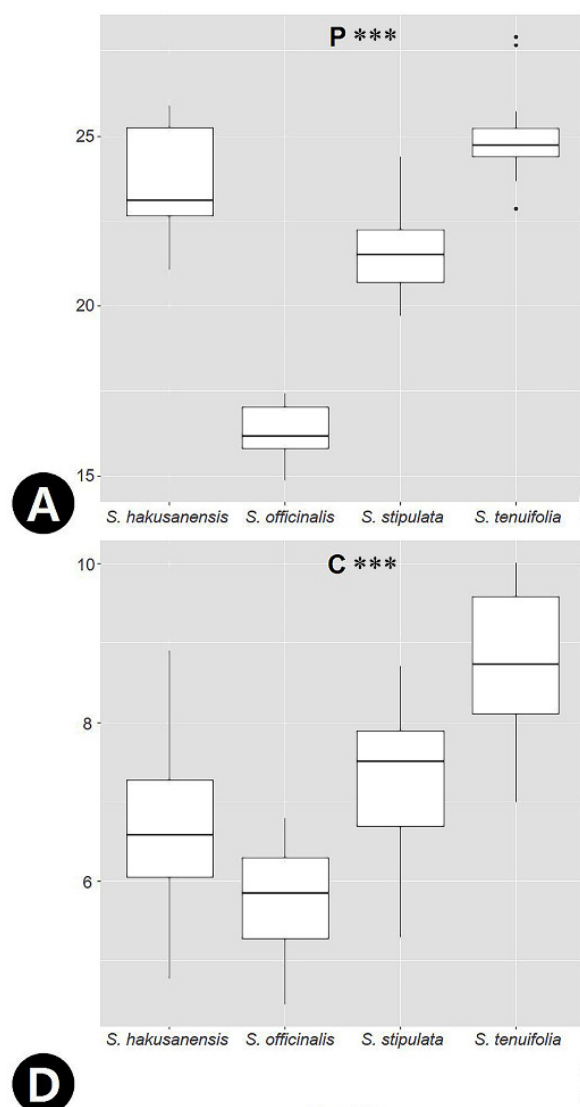

Species
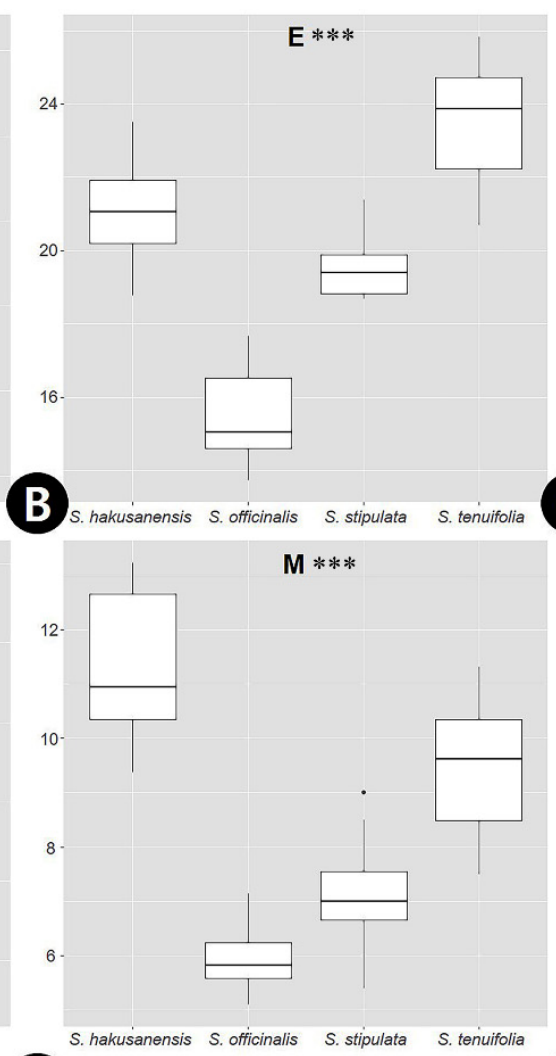

E

Species
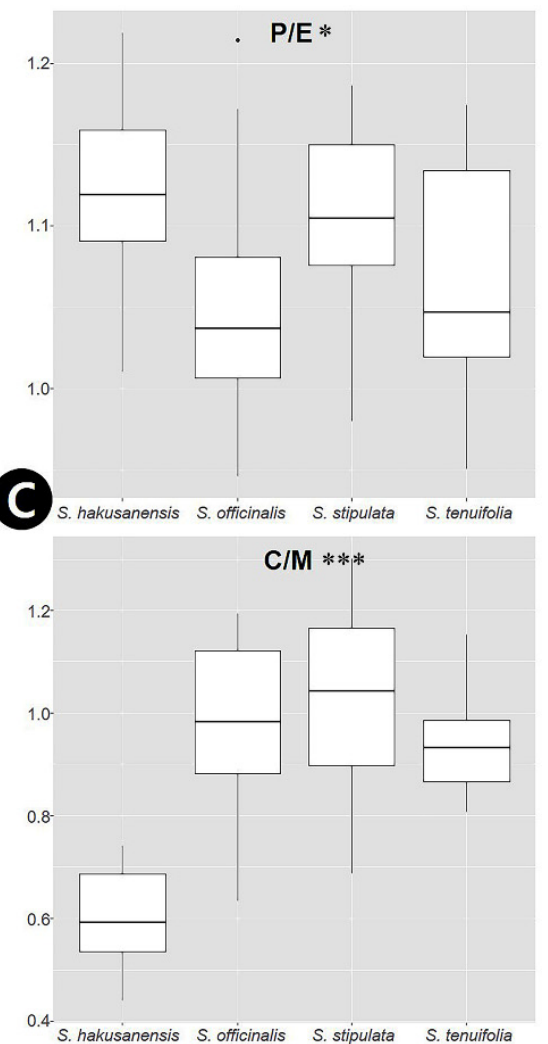

F

Figure 4. The quantitative data of the pollen morphological characteristics in Sanguisorba species. Boxplots show the median, 25th and 75th percentiles (box), 10th and 90th percentiles (whiskers), and outliers (closed circle). (A) Polar axis (P, $\mu \mathrm{m}),(\mathbf{B})$ Equatorial diameter $(\mathrm{E}, \mu \mathrm{m}),(\mathrm{C}) \mathrm{P} / \mathrm{E},(\mathrm{D})$ Colpus width $(\mathrm{C}, \mu \mathrm{m}),(\mathrm{E})$ Mesocolpus width $(\mathrm{M}, \mu \mathrm{m}),(\mathrm{F}) \mathrm{C} / \mathrm{M}$. The difference of characteristics is marked as significant with an asterisk based on an analysis of variance (ANOVA) test ( ${ }^{*}$; $\left.p<0.05 ;{ }^{* * *} ; p<0.001\right)$.

Based on the floral epidermal micromorphological and pollen morphological characteristics of the four Sanguisorba species, we provide the following identification key.

1. Outer sepal waxes platelets; hypanthium trichomes basal and ventral part;

tricolporate pollen grains; mesocolpus wider than colpus

$1^{\prime}$. Outer sepal waxes absent; hypanthium trichomes upper part or absent;

hexacolporate pollen grains; mesocolpus and colpus almost equal

2. Filament length 1-3 mm and filiform shaped; hypanthium ellipsoid; stigma fimbriae blunted apex

2' Filament length 5-8 $\mathrm{mm}$ and compressed-dilated; hypanthium globose; stigma fimbriae acute apex

3. Hypanthium trichomes absent

$3^{\prime}$. Hypanthium trichomes upper part
S. hakusanensis

2

S. officinalis

3

S. stipulata

S. tenuifolia

\subsection{The Chloroplast Genome Organization of Sanguisorba}

We sequenced three Sanguisorba accessions: S. officinalis, S. stipulata, and S. hakusanensis at approximately $380 \times, 805 \times$, and $397 \times$ coverage, respectively, generating $1.5-2.6 \mathrm{~Gb}$ raw paired-end reads and 0.9-1.7 Gb trimmed reads (Tables S1 and S2). The complete circular cp genome was 155,328-155,645 bp and matched the quadripartite structure of cp genomes, consisting of a pair of IRs $(25,562-25,593 \mathrm{bp})$ separated by the LSC $(85,444-85,697 \mathrm{bp})$ and SSC (18,760-18,788 bp) regions (Figure 5, Table 2). The complete cp genomes were of 
high quality (Figure S1 and Table S3). The overall GC content was approximately 37\%, which was slightly higher in the IR $(42 \%)$ than in the LSC $(35 \%)$ and SSC $(31 \%)$ regions. The four cp genomes comprised 112 genes, namely 78 protein-coding, four rRNA, and 30 tRNA genes (Table 2 and Figure S2). They had 18 intron-containing genes, 15 of which had a single intron and two of which (ycf3, clpP) had three introns with duplicate genes (ndhB, trnI-GAU, trnA-UGC) in the IR regions (Tables S4-S6). Analysis of codon usage and anticodon recognition patterns revealed 26,540-26,929 codons, among which leucine, isoleucine, and serine were the most abundant (Figure S3). To identify the codon patterns, we analyzed the codon distribution in the six cp genomes using the hierarchical clustering method (Figure S4); green and red colors indicate weak (relative synonymous codon usage, RSCU > 1) and strong (RSCU < 1) codon biases, respectively. Codons with A or T at the third position had a strong codon bias. Most Sanguisorba displayed a similar pattern, with high RSCU values for AGA (arginine), GCT (alanine), and TTA (leucine).

Table 2. Features of the Sanguisorba chloroplast genomes.

\begin{tabular}{|c|c|c|c|c|c|c|}
\hline Species & S. officinalis & S. stipulata & S. hakusanensis & S. tenuifolia & S. sitchensis & S. filiformis \\
\hline Accession number & In this study & In this study & In this study & MH513641 & NC_044691 & NC_044693 \\
\hline Total cp genome size (bp) & 155,412 & 155,403 & 155,645 & 155,403 & 155,127 & 154,282 \\
\hline Large single-copy (LSC) region (bp) & 85,478 & 85,444 & 85,697 & 85,525 & 85,347 & 84,405 \\
\hline Inverted repeat (IR) region (bp) & 25,573 & 25,562 & 25,593 & 25,576 & 25,615 & 25,609 \\
\hline Small single-copy (SSC) region (bp) & 18,788 & 18,760 & 18,762 & 18,726 & 18,550 & 18,659 \\
\hline Total number of genes (unique) & 112 & 112 & 112 & 112 & 112 & 112 \\
\hline Protein-coding gene (unique) & 78 & 78 & 78 & 78 & 78 & 78 \\
\hline rRNA (unique) & 4 & 4 & 4 & 4 & 4 & 4 \\
\hline tRNA (unique) & 30 & 30 & 30 & 30 & 30 & 30 \\
\hline GC content $(\%)$ & 37.2 & 37.2 & 37.2 & 37.2 & 37.2 & 37.3 \\
\hline LSC (\%) & 35.2 & 35.2 & 35.2 & 35.2 & 35.2 & 35.3 \\
\hline $\operatorname{IR}(\%)$ & 42.7 & 42.7 & 42.7 & 42.7 & 42.7 & 42.8 \\
\hline SSC (\%) & 31.2 & 31.2 & 31.3 & 31.3 & 31.4 & 31.4 \\
\hline
\end{tabular}

\subsection{The Repeat Sequences of the Sanguisorba Chloroplast Genomes}

To determine the character and proportion of repeat sequences in the Sanguisorba cp genomes, we surveyed the repeat sequences of Sanguisorba, such as forward, reverse, palindromic, and complementary repeats, yielding 49-50 repeats (Figure 6A). Furthermore, we compared the differences between the genera Bencomia and Sanguisorba. Sanguisorba had a similar number of repeats. For SSRs, the mononucleotide motifs were the most abundant in all Sanguisorba species, followed by dinucleotide motif repeats (Figure 6B). We identified 49-60 SSRs, mostly in the LSC, particularly within the intergenic spacer (IGS) region. Most tandem repeats were located in the IGS region (Figure 6C). We found 15-25 tandem repeats that were generally 21-40 bp long in Sanguisorba (Figure 6D). However, unlike other Sanguisorba, S. hakusanensis showed longer tandem repeats. Among the tandem repeats in IGS, repeats of five regions (trnK-rps16, atpF-atpH, trnC-petN, trnT-trnL, and accD-psaI) were common in the six Sanguisorba cp genomes. In the total repeat sequences, although the tandem repeats were fewer than other repeat sequences, it showed the highest length, and this pattern was similar in both Bencomia and Sanguisorba (Figure 6E). The number of repeat sequences was highest for $S$. hakusanensis, with a higher number of tandem repeats (Figure 6F). 


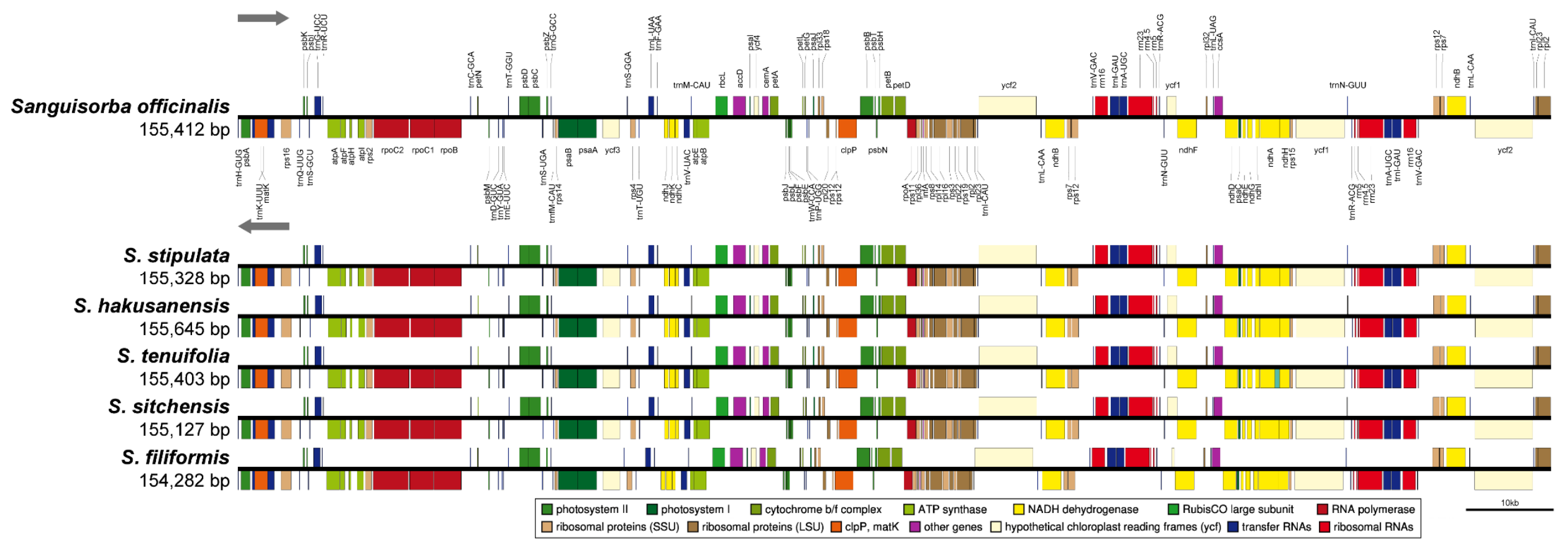

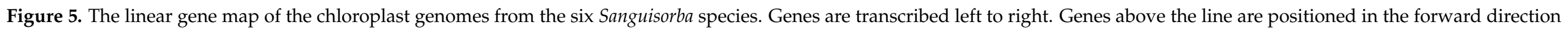
(left to right). Genes below the line are positioned in the reverse direction (left to right). 
A

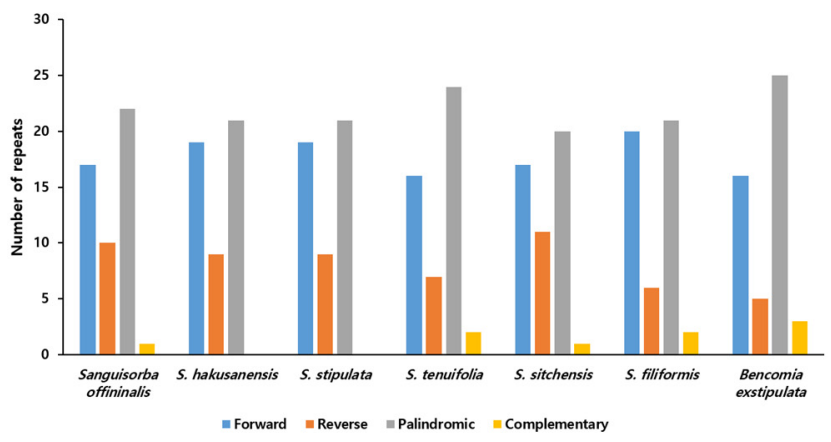

C

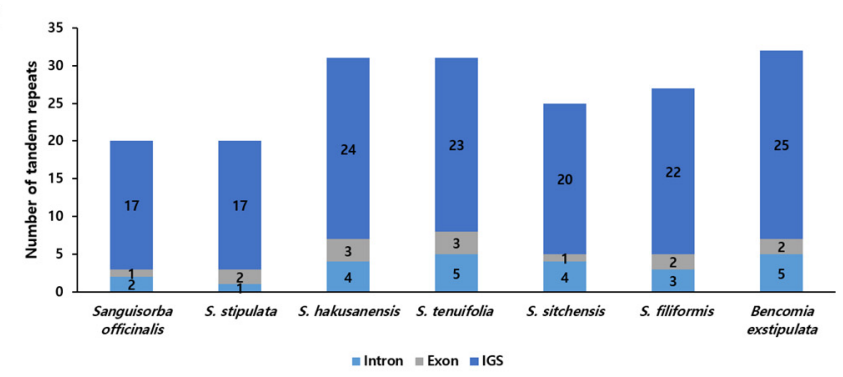

E

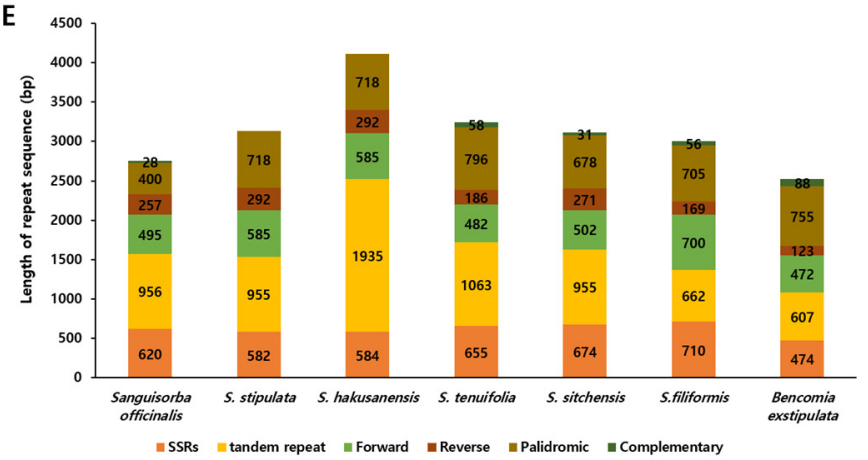

B

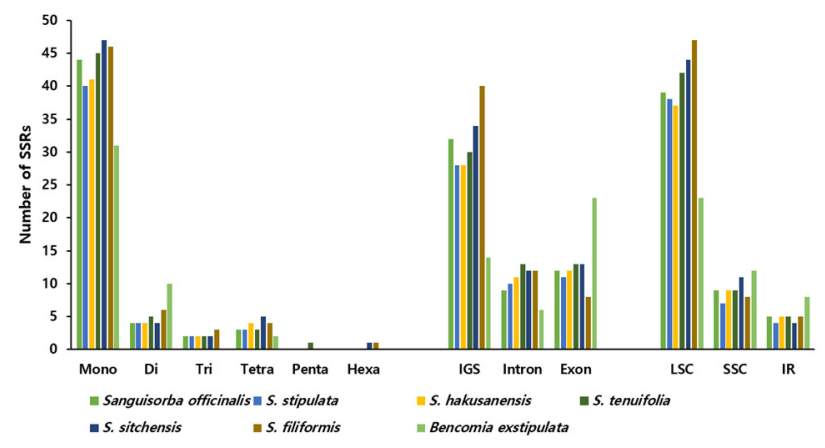

D
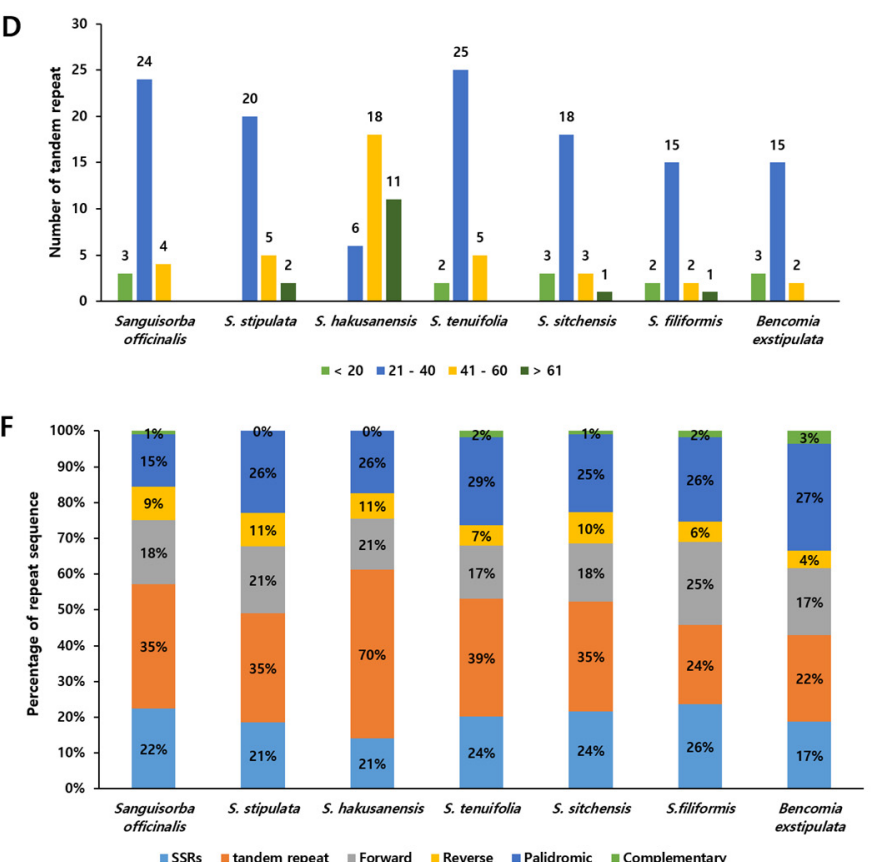

Figure 6. The distribution of the repeat sequences in Sanguisorba chloroplast genomes. (A) The number of single sequence repeats (SSRs) in genomic regions. (B) Distribution of SSRs in intergenic spacer (IGS), exon, and intron regions. (C) Distribution of SSR types. (D) Distribution of tandem repeats in genomic regions. (E) Distribution of tandem repeats in IGS, exon, and intron regions. (F) Distribution of lengths of the tandem repeats.

\subsection{Comprehensive Comparative Analysis of the Sanguisorba Chloroplast Genomes}

The sequence identities were analyzed using the mVISTA program, with the $S$. officinalis cp genome serving as a reference. Overall, the Sanguisorba cp genome structure was well conserved with that of Bencomia exstipulata (Figure 7). As expected, the genic regions were more conserved than the IGS regions when comparing each of the six species. The most divergent regions were detected in the IGS. The highest divergences were observed in the LSC and SSC regions. We analyzed genetic divergence using six Sanguisorba cp genomes, and species-specific mutations were detected using pairwise alignment by criterion in S. officinalis (Figure 8). We determined the Pi values for the six Sanguisorba cp genomes and species-specific Pi values. Overall, the Sanguisorba cp genome had an average $\mathrm{Pi}$ value of 0.008. The Sanguisorba cp genomes had divergent regions in the non-coding $\operatorname{trnH}-p s b A, \operatorname{trnR}$-atpA, rps2-rpoC2, and petB-petD in LSC and ccsA-ndhD in SSC. Furthermore, the $\operatorname{trnH}-p s b A$ had the highest Pi value of approximately 0.04 , followed by $\operatorname{trnR}$-atpA $(0.034)$ in the LSC regions. The species-specific mutations in S. officinalis and S. hakusanensis had the highest Pi values in $p s b Z-\operatorname{trn} G(0.082)$ and petB-petD $(0.041)$. However, the Pi values of $S$. officinalis and S. stipulata were more conserved than those of the other Sanguisorba species. 
As expected, the IR regions were more highly conserved than the single-copy regions. We also analyzed the syntenic regions and sequence identities within the six Sanguisorba species and Bencomia exstipulata (Figure S5). A few genome size variations were observed in S. filiformis. Overall, we found that the cp genomes of Sanguisorba were highly conserved in the genome structure and gene order compared to that of Bencomia exstipulata.
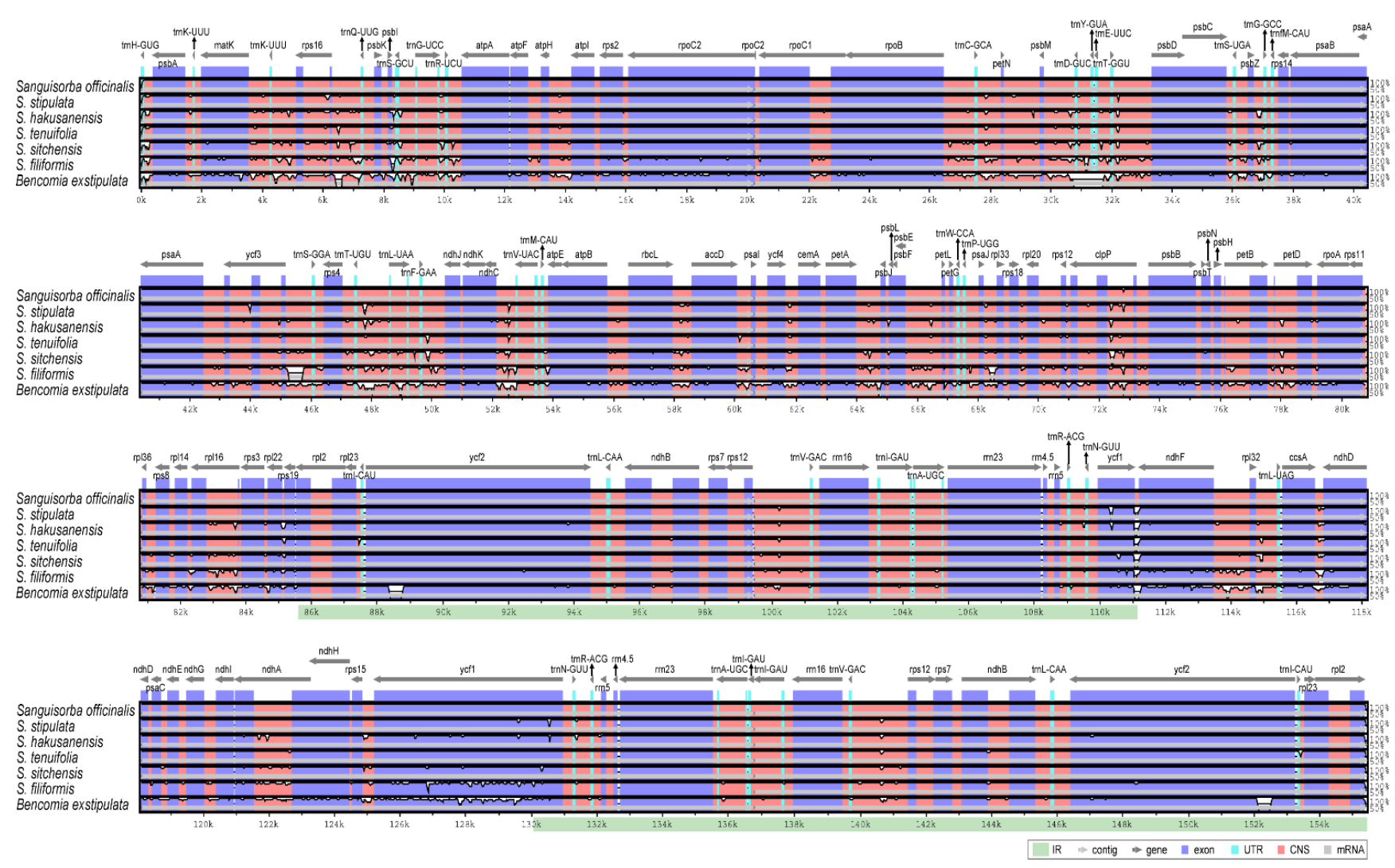

Figure 7. Comparison of the Sanguisorba chloroplast genomes using mVISTA. The complete cp genomes of six Sanguisorba species and Bencomia exstipulata were compared, with S. officinalis as a reference. Blue block: conserved genes, sky-blue block: transfer RNA (tRNA) and ribosomal RNA (rRNA), red block: conserved non-coding sequences (CNS). White represents the regions with sequence variation among the six Sanguisorba and Bencomia exstipulata.

We compared the IR contraction and expansion in the Sanguisorba cp genome (Figure S6). Similar IR lengths (ranging from 25,562 to 25,615 bp) and differences in the IR expansions and contractions were observed. The rps19 gene was observed to be located entirely in the LSC region. The ycf1 gene spanned the IRb/SSC and SSC/IRa junctions. The IRb/SSC border was also located in the ycf1 gene, although it extended by the same length into the $y c f 1$ gene. Overall, the IR was found to be expanded in all the cp genomes assessed. The trnH gene was located in the LSC region, 2-7 bp from the IRa/LSC boundary. The $r p l 2$ genes were duplicated in the IR regions flanking the border junctions. Generally, the Sanguisorba cp genome was highly conserved.

Based on the non-synonymous substitution to synonymous substitution $(\mathrm{Ka} / \mathrm{Ks})$ ratio, 78 genes were identified that showed evidence of selective pressure in the Sanguisorba cp genomes (Figure S7). Most genes were conserved and exhibited relaxed selection $(0<\mathrm{Ka} / \mathrm{Ks}$ ratio $<1)$. No significant gene evolution was observed according to the regional grouping (i.e., the LSC, IR, or SSC regions). Within the Sanguisorba cp genomes, 53 genes had Ka and Ks values of $>0.001$. The average Ka and Ks values were 0.0087 and 0.0546 , respectively. The highest Ks value for $r p l 2$ across the S. sitchensis cp genome was 0.1796 . The highest Ka/Ks ratios for $p s b K$ in S. stipulata and S. tenuifolia were 1.168 (Figure 9A). Among the Sanguisorba species, the $p s b K$ genes of S. stipulata and S. tenuifolia showed evidence of positive selection. In addition, S. filiformis showed positive selection for $n d h G(\mathrm{Ka} / \mathrm{Ks}$ 
ratio of 1.148) (Figure 9B). Thus, although the organization of the Sanguisorba cp genomes was highly conserved, positive selection pressures $(\mathrm{Ka} / \mathrm{Ks}>1)$ were observed for $p s b K$. Unlike other gene groups, $p s b K$ of the six Sanguisorba cp genomes showed varied patterns (Figure 9 and Figure S8).
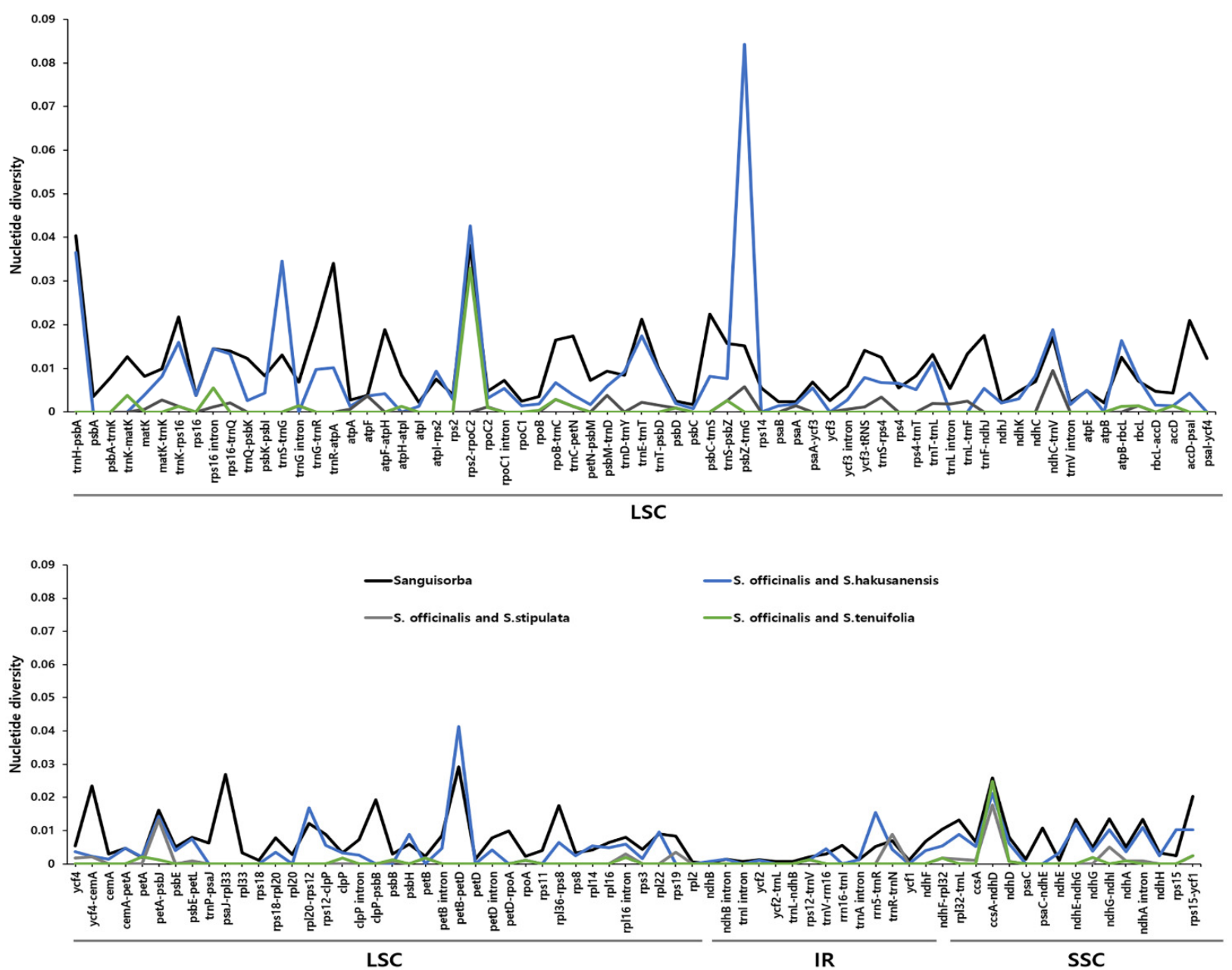

Figure 8. Comparison of the nucleotide diversity (Pi) values among the Sanguisorba. Pi value of Six Sanguisorba is indicated using a black line.

\subsection{New DNA Barcode for the Authentication of Sanguisorbae Radix}

The dried roots of S. officinalis and S. officinalis var. longifolia, collectively called Sanguisorbae Radix, are used as traditional herbal medicine in Korea [10]. S. officinalis and S. officinalis var. longifolia has been frequently mistaken with other similar Sanguisorba species due to similar morphological characterization, particularly as dried roots or powdered products. Therefore, SR should be distinguished to ensure the quality and efficacy of herbal medicines. We performed DNA barcoding analysis for distinguishing four species and one variety using the Internal transcribed spacer (ITS), matK (marker name; S_matK), rbcL (S_rbcL), ycf1 (Y1-1, Y1-2), matK-rps16 (MR16), and ycf3 intronic (Y3) regions (Figure S9). We obtained the sequences of four species and one variety consisting of ten samples (Table S7). In ITS, we did not find any nucleotide sequences to distinguish the Sanguisorba species (Figure S10). A total of six regions were considered for identifying the speciesspecific divergent regions. As Sanguisorba is not amplified with the universal DNA barcode primers, $m a t K$ and $r b c L$, we designed and applied primers from the cp genome information (Figure S8). S_matK, S_rbcL, MR16, and Y1-1 had the most variable sites (P $=0.00296$ for S_matK, 0.002 for S_rbcL, 0.00466 for MR16, and 0.00699 for Y1-1) among the four species 
and one variety (Table 3). They exhibited 5 (1.2\% in MR16) to 7 (0.8\% in S_rbcL) parsimony informative sites. The number of haplotypes was indicated to be one to four. Thus, there were no mutations that could cover the four species and one variety in one region. The three regions (matK-rps16, ycf1, and ycf3 intron) could represent the species-specific variability using indel mutations (Table 3 and Figure S11). The aligned DNA barcode sequences in the six Sanguisorba are shown in Figure S11. S. stipulata could be identified with a unique nucleotide in the S_matK region of $689 \mathrm{bp}$. The S_rbcL marker yielded $870 \mathrm{bp}$ region, distinguishing four nucleotides from $S$. hakusanensis and one nucleotide from $S$. officinalis, and thereby could be used to discriminate S. hakusanensis and S. officinalis from other Sanguisorba species. Indel variants of S. hakusanensis were distinguished using the MR16 marker. Y1-1 yielded a 214 bp region, with one nucleotide for distinguishing S. officinalis var. longifolia, which was distinct from that of S. hakusanensis and S. stipulata for Y3.

A

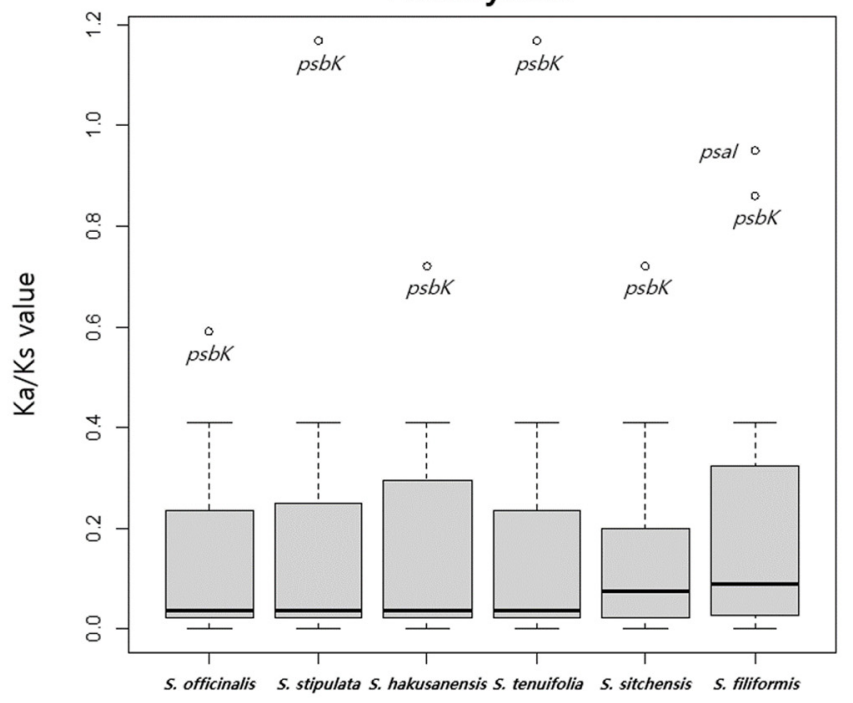

\section{B}

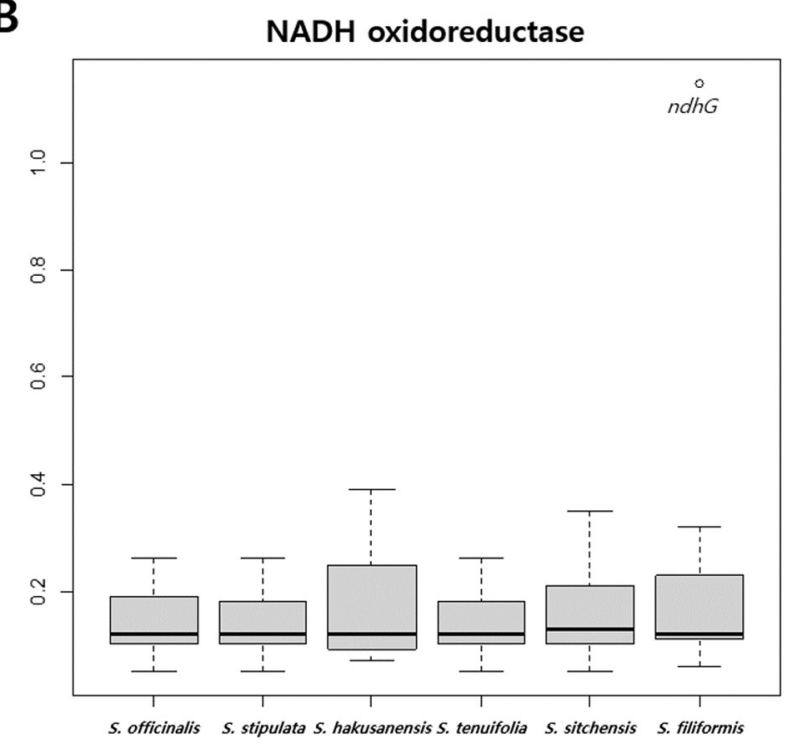

Figure 9. $\mathrm{Ka} / \mathrm{Ks}$ values for (A) the photosystem- and (B) NADH oxidoreductase-related genes in the Sanguisorba cp genomes.

Table 3. The analysis of DNA barcodes of four Sanguisorba species and one variety.

\begin{tabular}{|c|c|c|c|c|c|c|c|c|}
\hline \multirow{2}{*}{ Species } & \multirow{2}{*}{ Region } & \multirow{2}{*}{$\begin{array}{l}\text { Marke } \\
\text { Name }\end{array}$} & \multirow{2}{*}{$\begin{array}{c}\text { Aligned } \\
\text { Length (bp) }\end{array}$} & \multicolumn{2}{|c|}{ Parsimony Informative Site } & \multirow{2}{*}{$\begin{array}{c}\text { Nucleotides } \\
\text { Diversity (Pi) }\end{array}$} & \multirow{2}{*}{$\begin{array}{l}\text { Length of } \\
\text { Indel }\end{array}$} & \multirow{2}{*}{$\begin{array}{l}\text { Number o } \\
\text { Haplotype }\end{array}$} \\
\hline & & & & Number & $\%$ & & & \\
\hline \multirow{6}{*}{ Sanguisorba * } & matK & S_matK & 689 & 6 & $0.9 \%$ & 0.00296 & 0 & 3 \\
\hline & $\mathrm{rbcL}$ & S_rbcL & 870 & 7 & $0.8 \%$ & 0.00200 & 0 & 3 \\
\hline & matK-rps16 & MR16 & 409 & 5 & $1.2 \%$ & 0.00466 & 22 & 2 \\
\hline & ycf1 & Y1-1 & 214 & 5 & $2.3 \%$ & 0.00699 & 0 & 2 \\
\hline & ycf1 & Y1-2 & 346 & 0 & $0.0 \%$ & 0 & 12 & 1 \\
\hline & ycf3 intron & Y3 & 346 & 0 & $0.0 \%$ & 0 & 42 & 1 \\
\hline
\end{tabular}

* S. hakusanensis, S. officinalis, S. officinalis var. longifolia, S. stipulata, S. tenuifolia.

\subsection{The Phylogenetic Relationships among Sanguisorba}

To verify the phylogenetic relationships among the members of the Sanguisorba, we identified 57 conserved protein-coding sequences by aligning 55,760 bp shared by all the six Sanguisorba species with Agrimonia pilosa and Hagenia abyssinica serving as outgroups (Figure 10). The maximum likelihood (ML) and Bayesian inference (BI) topologies were highly congruent with the whole genome sequences and CDS datasets (Figure S12). The phylogenetic analyses strongly supported all but one lineage $(\mathrm{ML}=100 \%, \mathrm{BI}=1.0)$. Six Sanguisorba in the tribe clustered well. S. tenuifolia, S. officinalis, and S. stipulata formed a monophyletic group. S. hakusanensis was positioned as a sister group. Overall, the cluster- 
ing revealed that S. tenuifolia and S. officinalis shared the closest phylogenetic relationship, with $S$. filiformis as their sister group and Bencomia exstipulata distinct from Sanguisorba.

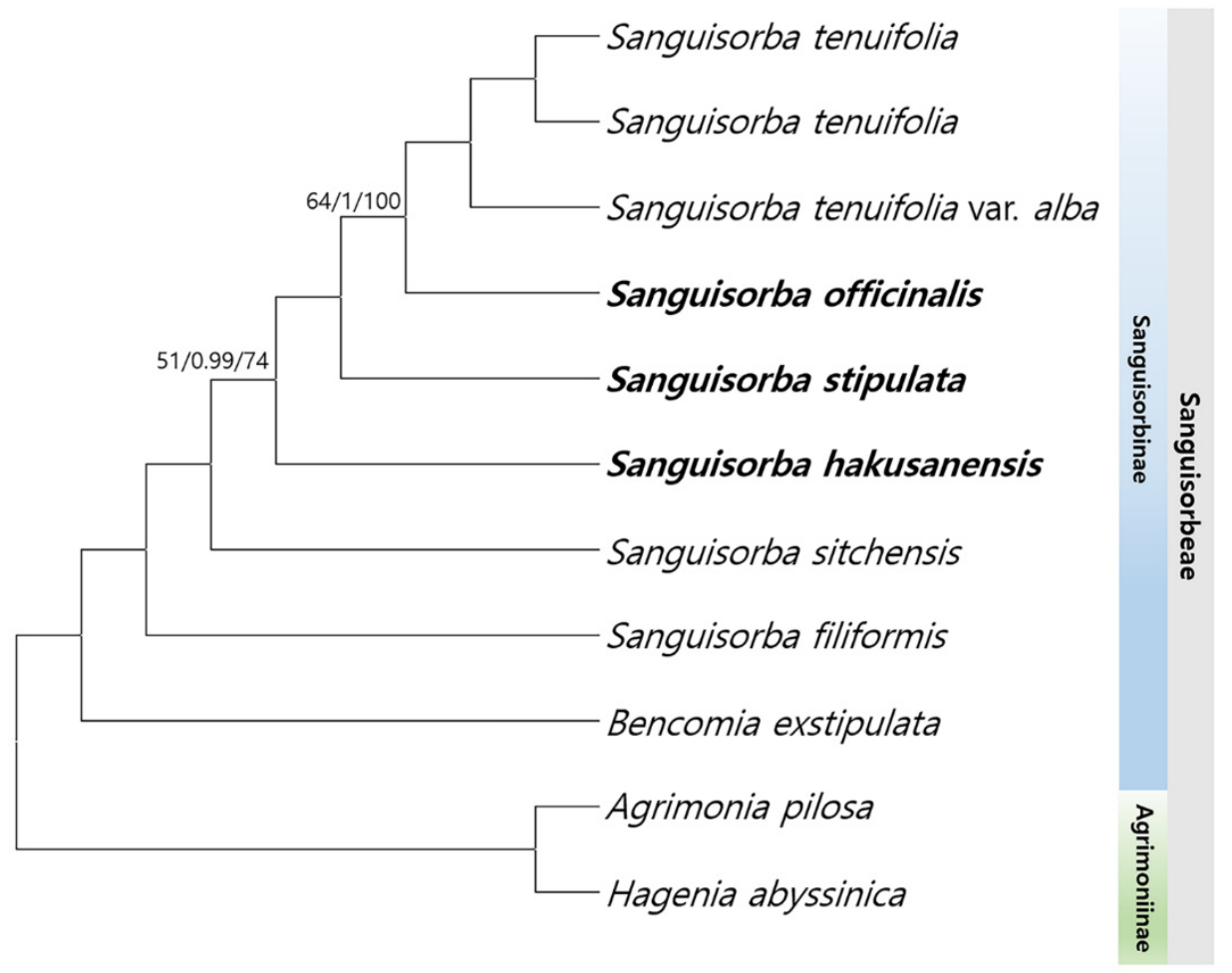

Figure 10. Phylogenetic tree from the Sanguisorba using maximum parsimony (MP), Bayesian posterior probabilities (PP), and maximum likelihood (ML) bootstraps. Topology is shown with MP bootstrap values/Bayesian PP/ ML bootstrap support values given at each node. MP and ML values of $100 \%$ and Bayesian inference (BI) PP of 1.0 are not marked. The cp genomes completed in this study are indicated with bold text.

\section{Discussion}

Sanguisorba species showed substantial diversity with respect to the androecium (filament), gynoecium (stigma), the hypanthium, and pollen grains (aperture and colpus pattern). However, all studied species shared similar cellular surface patterns of floral parts such as sepal, hypanthium, style, stigma, exine ornamentation, and orbicule distribution. The members of the Sanguisorba are apetalous flowers (lacking petals), and their sepals look like petals. The surface pattern of sepal, smooth on the outer (abaxial) and slightly convex with striation on the inner (adaxial) surface, was similar to that of other insect-pollinated flowers [44]. A recent study suggested a possible shift in the pollination mechanisms in this genus because both anemophilous and entomophilous characters are present [19]. Thus, our sepal micromorphological data of Sanguisorba may provide additional evidence of insect pollination as a role of petals.

Epicuticular waxes are hydrophobic substances present on the surfaces of land plants. Their various shapes and distribution patterns, especially on the leaves and stem surfaces, have proven useful for taxonomic studies [45-51]. Recently, the floral waxes of sepals, petals, and labella of the following genera have provided valuable diagnostic characteristics: Justicia [52], Corybas [53], Crepidium [54], and Paphiopedilum [55]. In this study, the platelet waxes were only found on the outer sepals of $S$. hakusanensis. We identified the possibility of taxonomical application of the floral waxes, although further studies including all the Sanguisorba species are required. Moreover, epicuticular waxes, as direct plant interfaces, reportedly have multifunctional properties [56]. In particular, they control the water loss and reduce transpiration rates [57], and epicuticular waxes are one of the xeromorphic cuticle features [58]. Among the studied species, floral wax is only found 
in the S. hakusanensis growing in the alpine region. Thus, further study of the ecological implications of the leaf epicuticular waxes in Sanguisorba is also required.

The hypanthium and stigma characteristics were helpful for the identification of the Sanguisorba species. Four Sanguisorba species could be distinguished into two groups based on the shape of the hypanthium: ellipsoid and globose. This pattern is consistent with the observations of Wang et al. [19] for S. tenuifolia var. alba (their Figure 3), S. hakusanensis (their Figure 7E), and S. officinalis (their Figure 9). However, the disk-like structures and style shapes were not consistent. The degree of development of the disk-like structure was different for S. tenuifolia (Figure 1L) and S. tenuifolia var. alba (Figure 4F). S. tenuifolia var. alba had a thickened disk-like structure, unlike that of S. tenuifolia. To confirm their taxonomic usefulness, research that covers all species is required. Although almost all samples collected at anthesis were observed in the bent style, some flowers of the same individual had a straight style. Thus, this feature was inconsistent and unusable for identification. All the Sanguisorba species have a fimbriate stigma [4-8]; however, their fimbriae lobation and apex shape differed. The stigma surface area is closely related to the pollination mechanisms and efficiency [59]. Thus, a more detailed correlation between the stigma receptivity, different shapes, and surface areas and their pollination efficiency in this genus is required.

Most androecium characters, such as dorsifixed anthers, striation surface cell pattern of the outer anther, and filament, were similarly shared among all the studied species. However, S. officinalis could be easily distinguished from other species based on the shortest (shorter than sepal) and filiform filaments. The remaining three species had relatively long (longer than sepal) and compressed-dilated filaments. Long filaments exposing anthers are efficient for wind pollination from an aerodynamics perspective, particle transport by air, and capture $[59,60]$. Thus, differences in the filament characteristics might be a result of selection by different pollinators. Verification of the relationship between the pollination mechanism and filament shape is needed to understand their adaptation and pollination biology.

The palynological variation of the studied species is less diverse, except for the aperture number. Although most of the Rosaceae taxa had tricolporate pollen $[28,29,61,62]$, tetra- and hexacolporate pollen were also found in the tribe Sanguisorbeae $[17,18]$. The tri-colporate pollen of S. hakusanensis and hexacolporate pollen of S. tenuifolia and S. stipulata in this study are consistent with the observations of Lee et al. [18]. According to the authors, the aperture of $S$. officinalis has been recognized as tricolporate $[17,27,61]$ or hexacolporate [63-65]. Thus, the aperture type of S. officinalis pollen grains remains controversial. Most $S$. officinalis pollen grains were observed as hexacolporate, although some were confused for tricolporate or hexacolporate. The apertures are where the pollen tube emerges and breaks through the wall at the time of germination [66,67]. Thus, $S$. officinalis pollen grains, which have places for six emerging pollen tubes, are hexacolporate from a plant growth point of view.

Orbicules (or Ubisch bodies) are small and granular particles found in the inner locule wall of mature anthers and are composed of sporopollenin [68-71]. In the Rosaceae, the occurrence of orbicules represents the consistency within the tribe in Sorbarieae [31], Neillieae [32], and genera in Luetkea, Sibiraea, and Xerospiraea [33]. Orbicules have been consistently absent in all the taxa investigated; therefore, the absence of orbicules in Sanguisorba might be a possible synapomorphic character.

In this study, we determined the complete cp genomes of three Sanguisorba species. The Sanguisorba cp genomes were similar to those of the other Sanguisorbeae cp genomes, based on a typical quadripartite structure. The Sanguisorba cp genomes were found to have 112 unique genes; however, their gene order, GC content, genomic structure, and overall length $(155,403-155,644 \mathrm{bp})$ were within the range of the previously described Sanguisorbeae cp genomes $[42,43,72,73]$. Codon usage is a key factor in the correct expression of genetic information, and it plays an important role in shaping cp genome evolution [74,75]. The Sanguisorba have nearly the same codons as the cp genomes of Bencomia exstipulata. The 
RSCU values indicated synonymous codon usage bias, with a disproportionate number of amino codons having an A or $\mathrm{T}$ as their third nucleotide. This phenomenon has been observed in many angiosperm cp genomes $[74,76,77]$. We also surveyed the RSCU values of the Sanguisorba cp genomes. Half of the codons had a weak codon bias (Figure S4), denoted in green in the figure (RSCU > 1). This result is similar to that of other cp genomes, and most codons with high RSCU values had an A or T in the third position of their amino acid. In particular, the TAC (tyrosine), GAC (aspartic acid), and CGC (arginine) codons had relatively low RSCU values. The RSCU values of the Sanguisorba cp genomes were consistent with those of the other higher plants. The high RSCU values corresponded to the more highly conserved cp genes.

The repeat sequence affects the length of the genome and is one of the factors that indicate the characteristics of the genome, such as structural variation, gene loss, orientation, and duplication $[34,78,79]$. We analyzed the repeat sequence of Sanguisorba by dividing it into six types (forward, reverse, complementary, palindromic, SSRs, tandem repeat) compared to that of Bencomia (Figure 6). In the case of general repeats, Sanguisorba was similar to Bencomia, and there was very little difference between the species. General repeats appeared in a small proportion of the entire repeat sequence. In the SSR consisting of 1-6 nucleotides, mononucleotide repeats occupied the most in the single-copy regions (LSC, SSC). This finding agrees with previous reports, where the most mononucleotide repeats were $\mathrm{A}$ and $\mathrm{T}$ repeats due to an abundance of polyamines and polythymines in the cp genome [37,80]. Defining SSRs in Sanguisorba cp genomes could provide useful genetic resources for species identification and population genetics. Tandem repeats of 2 to 4 nucleotides long were detected in the repeat sequences of the Sanguisorba cp genomes, most of which were $20-40 \mathrm{bp}$ in length. Tandem repeats in S. hakusanensis were significantly more compared to other species and accounted for $70 \%$ of the total length of the repeat. The tandem repeats of $S$. hakusanensis might indicate that the genetic variation of this species is greater than that of other Sanguisorba species. The tandem repeats in other Sanguisorba species accounted for more than $35 \%$ of the total repeats, and S. filiformis had similar tandem and forward repeat proportions. Overall, the tandem repeats of Sanguisorba showed a significant difference compared to that of Bencomia and showed unique characteristics of the Sanguisorba cp genomes.

The mVISTA results showed that the cp genomes of the Sanguisorba species have low diversity. Their genic regions are more conserved than their IGS regions, with the latter observation being consistent with that previously observed for cp genomes of the same genus [43]. In terms of nucleotide diversity, most divergent regions are non-coding, which is generally consistent with that for other $\mathrm{cp}$ genomes. Other $\mathrm{cp}$ genomes were reported to have highly variable non-coding sequences at $t r n H-p s b A, \operatorname{trnR}$-atpA, $r p s 2-r p o C 2$, and petB-petD in the LSC regions and at $\operatorname{css} A-n d h D$ in the SSC regions (Figure 8). These regions were previously found to be hotspots for genetic variation [81-84]. We performed a detailed comparative analysis for each species, using S. officinalis as the standard because S. officinalis is an important herbal medicine resource. As expected from the phylogenetic relationship, S. officinalis was similar to $S$. tenuifolia. They showed little difference, except in some regions. However, S. officinalis and S. hakusanensis showed the greatest differences, especially in the species-specific divergent region ( $p s b Z-\operatorname{trn} G)$. This area was mainly conceived as poly (A), poly (T), and poly (AT) and exhibited a large variation under the influence of this repeat. Compared to other species, it appeared to be species-specific for S. hakusanensis. We noticed that the repeat sequences affected the diversity. Overall, the genetic variations showed very similar patterns within the Sanguisorbeae family. Our results indicate that the hotspot region includes these variable regions. The IR regions are known to be more highly conserved than the single-copy regions. The hotspot regions of plant species in the Sanguisorbeae family indicate underlying evolution and can be used as DNA barcodes to distinguish species or genera, depending on the variabilities of the regions.

The IR contraction and expansion in the angiosperm cp genomes causes the cp genome size to vary [85]. Previous studies have identified extremely short IRs or the loss of the 
IR regions and genes [86,87]. The family Sanguisorbeae is highly conserved in terms of the IR length and position. However, we found that the lengths of the IR regions ranged from 25,562 to $25,609 \mathrm{bp}$, indicating that some contraction/expansion occurred in the IR regions (Figure S6). The rps19 gene is located in the LSC region, and ycf1 was identified at the IR/SSC junction; $n d h F$ was positioned in the SSC region based on the overlapping region in Bencomia exstipulata. Thus, the Sanguisorba cp genome has a contracted IR. This phenomenon has been observed in other Sanguisorba cp genomes [43]. rpl2 exhibited gene duplication in IRs compared to the dicotyledon cp genomes [34]. Although the genome structure of the IR region was highly conserved among the cp sequences of the Sanguisorba species, extreme gene shifting and duplication have occurred in the Sanguisorba genus. Taken together, these findings indicate that the cp genomes of the Sanguisorba members are highly similar and conserved.

To determine the selection pressure in the protein-coding genes, the $\mathrm{Ka} / \mathrm{Ks}$ ratios from the collinear genes were examined as evolutionary markers (Figure S7). The most conserved genes exhibited purifying selection (Ka/Ks ratios, 0-0.183). The Sanguisorba members had two positively selected genes, $n d h G$ and $p s b K$, which underwent selective pressure in the S. filiformis, S. stipulata, and S. tenuifolia $\mathrm{cp}$ genomes, respectively. There is an indication of species-specific selection pressures. The positive selection pressures for the $n d h G$ and $p s b K$ genes are commonly observed in the angiosperm cp genomes [88-91]. The $n d h G$ genes encode for one of the eleven $n d h$ subunits of the Ndh1-complex. The $p s b$ genes encode the photosystem II that consists of 17 subunits. Among them, 15 subunits are present in the $\mathrm{cp}$ genome [34]. Genes showing positive selection are considered to undergo adaptive evolution in response to their environment. To confirm the speciesspecific positive selection, the pattern of positive selection of the gene group was confirmed (Figure 9 and Figure S8). $n d h G$ was predicted to be affected by the species-specific selection pressure. However, among the photosystem II-related genes, the $p s b K$ gene was affected by the selection pressure compared to other genes, and it was possible to confirm that it was affected at the genus level. In particular, S. filiformis showed a higher level of selection pressure than $p s b K$, although $p s b I$ was also a purifying selection factor. As a result, it was shown that Sanguisorba was influenced by the environment at the time of differentiation. When looking at the results of $n d h G$ and $p s b I$ of $S$. filiformis, it is inferred that the selection pressure by the environment acted after species differentiation.

Beyond these results, Sanguisorba showed no dynamic variants in the cp genome compared to Bencomia. The cp structure and gene order were very similar, with some genes associated with a positive selection pressure. These findings provide evidence of adaptation to environmental changes during the evolutionary process of Sanguisorba and show differences at the tribe and the family levels. The gene-selection pressure suggests that the genes of interest are undergoing essential adaptations to their environment.

Differentiation of herbal medicines and species identification of plant origin are recognized as important factors in the standardization of herbal medicines [23,39]. As molecular markers are a very efficient and objective method compared to morphological discrimination, they are used as essential elements for the differentiation of oriental medicines or species identification. In particular, DNA barcodes are widely used to identify herbal medicines [92-94]. In addition, because information on the cp genome can be easily recognized with the development of NGS technology, many studies have reported the development of markers using genetic variations such as indels and SNPs through genome comparison [95-97].

We developed new DNA barcode sets to distinguish the authentic and adulterant Sanguisorba. The dried roots of S. officinalis and S. officinalis var. longifolia, used in traditional herbal medicine in Korea was studied [10,11]. These are valuable herbal medicinal plants that are indiscriminately used with other Sanguisorba species. They are frequently used without species identification because their root shape is similar to that of other Sanguisorba species. First, we analyzed the ITS regions; however, they are highly conserved, without genetic variants in Sanguisorba. A previous study showed that 18S-5.8S-26S rDNA sites 
are highly conserved in Sanguisorba caused by common polyploidization in Rosaceae [97]. The species-specific nucleotides did not appear in the ITS region because of the ploidy effect of Sanguisorba. For efficient barcode analysis, ploidy analysis of the relevant species or acquisition of prior information is required. Thus, Sanguisorba is not suitable for the identification of species with ITS barcodes. Therefore, we applied a universal and novel DNA barcode region in the cp genome. mat $K$ and $r b c L$ are widely used as universal DNA barcodes. A previous study reported that $m a t K$ and $r b c L$ primers were not amplified in Sanguisorba [97]. Therefore, we designated a stable region without mutation as a primer based on information obtained from the cp genome, and a stable amplification product was obtained from S_matK and S_rbcL as well as other regions such as matK-rps16 (MR16), ycf1 (Y1-1, Y1-2), and ycf3 intron (Y3). Our newly developed Sanguisorba-only DNA barcodes can ultimately discriminate between S. officinalis and S. officinalis var. longifolia. In particular, the $y c f 1$ gene had a unique nucleotide for S. officinalis and S. officinalis var. longifolia. In addition, $S$. hakusanensis had multiple barcode regions in the matK, $r b c L$, matK-rps16, and $y c f 3$ introns. We have successfully developed molecular markers that can distinguish $S$. officinalis and S. officinalis var. longifolia from the other Sanguisorba species.

The marker developed by utilizing the information obtained from the cp genome will be a valuable tool for quality check or species identification of the Sanguisorba species and Sanguisorbae Radix. It will be of great help in the production of highly pure herbal ingredients.

The $\mathrm{cp}$ genomes provide valuable genomic resources for accurately determining phylogenetic relationships, particularly among the closely related species and unresolved taxa, because of their infrageneric complexity and the differences in species concepts among authors $[23,98]$. Previous studies have indicated weak relationships among the Sanguisorba species in Rosaceae because they used insufficient genetic information. Meng et al. [43] presented a phylogenetic study of Sanguisorba, which included 10 Sanguisorba species based on the cp loci in the matK region. S. hakusanensis and S. stipulata as well as S. officinalis and S. tenuifolia were monophyletic. The present study found them to be paraphyletic with a high resolution. Meng et al. [43] reported phylogenetic relationships for the cp genomes of the four Sanguisorba species. These results are consistent with those of our study (Figure 10).

As described above, since Sanguisorba shows characteristics of a highly conserved cp sequence, it is very difficult to analyze the species relationship via phylogenetic analysis with some cp loci. In our results, the ML and BI trees had a lower resolution in S. officinalis and S. stipulata (Figure S10). However, our results demonstrated the species identification and phylogenetic relationship of Sanguisorba. This study can be the basis for research on Sanguisorba and the tribe Sanguisorbeae. Although additional analysis is warranted, it is a valuable study in a context where very little information about the genome of Sanguisorba is available.

\section{Materials and Methods}

\subsection{Plant Materials}

The plant material used in this study was collected from the natural populations. Original descriptions and other relevant taxonomic literature were searched and used for the accurate identification of all the studied species.

Identification numbers were assigned to all the samples. The voucher specimens were deposited in the Korean Herbarium of Standard Herbal Resources (Index Herbariorum code: KIOM) at the Korea Institute of Oriental Medicine, Naju, Korea. Information about the samples used for micromorphological, palynological, and plastid genome sequence analyses and marker tests are listed in Table S7.

\subsection{Microscopic Observations}

For detailed floral micromorphological and palynological observations, fully mature reproductive organs were examined using a stereomicroscope (SZX16; Olympus, Tokyo, Japan). All the studied materials were in the same anthesis stage. For SEM, the dried 
samples from the voucher specimens were rehydrated overnight in a wetting agent (Agepon: distilled water, 1:200) (Agfa Gevaert, Leverkusen, Germany). The floral samples, including pollen, were dehydrated using a graded series of ethanol $(50,70,90,95$, and $100 \%$ ethanol) at room temperature $\left(25^{\circ} \mathrm{C}\right)$ for $1 \mathrm{~h}$ at each ethanol concentration. The dehydrated material was immersed in liquid $\mathrm{CO}_{2}$ for CPD (SPI-13200JE-AB; SPI Supplies, West Chester, PA, USA) and subsequently mounted on aluminum stubs using a double-sided adhesive conductive carbon disk (05073-BA; SPI Supplies, West Chester, PA, USA). All samples were gold-coated using an ion-sputtering device (208HR; Cressington Scientific Instruments Ltd., Watford, UK) and observed using a low-voltage field-emission scanning electron microscope (JSM-7600F; JEOL, Tokyo, Japan) at an accelerating voltage of 5-10 kV and a working distance of 5-10 $\mathrm{mm}$.

The measurements were based on at least 20 pollen grains. Six variables, namely $\mathrm{P}$ (polar axis), E (equatorial diameter), P/E, C (colpus width), M (mesocolpus width), and $\mathrm{C} / \mathrm{M}$, were determined based on the SEM micrographs and measured using the Digimizer software (Digimizer version 5.4.3, MedCalc Software, Mariakerke, Belgium). To demonstrate the variations in these variables, species boxplots were generated using the ggplot2 library [99] in the R package (version 3.6.3; R Foundation for Statistical Computing, Vienna, Austria). Moreover, a one-way analysis of variance (ANOVA) was also performed to test the significance of differences in quantitative pollen data. The pollen terminology was based on those proposed by Punt et al. [66] and Verstraete et al. [100].

\subsection{Genome Sequencing and Assembly}

The total DNA of the four tested species was extracted using a modified CTAB method [101]. Four libraries were prepared from the total genomic DNA using the TruSeq DNA Nano Kit following the manufacturer's protocols and the NextSeq500 platform (Illumina, San Diego, CA, USA), generating $1.5-2.6 \mathrm{~Gb}$ of paired-end $(2 \times 150 \mathrm{bp})$ reads. The generated reads were trimmed, and their quality was checked using the CLC quality trim implemented in the CLC Assembly Cell software (version 4.2.1; CLC Inc., Aarhus, Denmark). The trimmed paired-end reads (Phred score $\geq 20$ ) were assembled using the CLC genome assembler (ver. 4.2.1; CLC Inc.) with default parameters. The SOAP de novo gap was used to fill the gaps based on the alignment of paired-end reads [102]. The contigs were aligned against the NCBI nrDB to detect $\mathrm{cp}$ contigs and were retrieved from the total contigs using Nucmer [103]. The aligned contigs were ordered using the cp genome sequences of Rosa odorata (KF753637), S. officinalis (MF678801), S. filiformis (MF678800), S. stipulata (MF678798), and S. tenuifolia var. alba (MF678799) as the reference. The complete cp genomes were validated by PCR-based sequencing using sequence-specific primers (Table S8). The PCR products of the four junctions (LSC/IRa, IRa/SSC, SSC/IRb, and $\mathrm{IRb} / \mathrm{LSC}$ ) were compared to complete the cp genome sequences. Finally, the total trimmed paired-end reads were mapped onto the complete genome sequences using BWA ver. 0.7.25 [104] (Figure S1). The new cp genome sequences of S. officinalis, S. stipulata, and S. hakusanensis obtained in this study were deposited in the NCBI GenBank database under the accession numbers MZ145057, MZ145058, and MZ145059.

\subsection{Genome Annotation and Comparative Analysis}

The gene annotation of the S. officinalis, S. stipulata, and S. hakusanensis cp genomes was performed using GeSeq [105], and the annotation results were concatenated using an in-house script pipeline. The protein-coding sequences were manually curated and confirmed using Artemis [106] and checked against the NCBI protein database. The tRNAs were confirmed using the tRNAscan-SE 1.21 [107]. The IR region sequences were confirmed using an IR finder and RepEx [108]. Circular maps of the S. officinalis, S. stipulata, and S. hakusanensis cp genomes were obtained using OGDRAW [109]. The GC content and RSCU of the four cp genomes were analyzed using the MEGA7 software [110]. The codon usage distribution of six Sanguisorba cp genomes was visualized using the Heatmapper program, with the average linkage of clustering and Euclidean distance measurement methods [111]. 
An RSCU $<1.00$ indicated a codon that was used less frequently than expected, whereas an RSCU > 1.00 indicated a codon that was used more frequently than expected. The MAUVE V2.3.1 [112] was used to identify local collinear blocks of seven Sanguisorbinae (S. officinalis, S. stipulata, S. hakusanensis, S. tenuifolia, S. sitchensis, S. filiformis, and Bencomia exstipulata). The mVISTA program in the Shuffle-LAGAN mode was used to compare the cp genomes with Rosa odorata (KF753637) as a reference. The DnaSP version 6 [113] was used to calculate the nucleotide variability $(\mathrm{Pi})$ among the $\mathrm{cp}$ genomes. To confirm the exact genetic variants, the CDS, introns, and IGS regions were analyzed separately. The substitution rates Ka and Ks of six Sanguisorba species were estimated using the KaKs Calculator ver. 2.0 [114] with Bencomia exstipulata as a reference.

\subsection{Repeat Analysis}

We used the REPuter to find forward, reverse, palindromic, and complementary repeats with a minimal length of $20 \mathrm{bp}$, an identity of $90 \%$, and a hamming distance of 3 [115]. The SSRs were detected using MISA [116], with the minimum number of repeat parameters set to 10, 5, 4, 3, 3, and 3 for mono-, di-, tri-, tetra-, penta-, and hexanucleotides, respectively. Tandem repeats $\geq 20$ bp were identified using the Tandem repeats finder [117] with a minimum alignment score of 50 and a maximum period size of 500; the identity of repeats was set to $\geq 90 \%$.

\subsection{Development of New DNA Barcodes for Distinguishing Sanguisorba}

To detect species-specific variation, the genetic variant region was confirmed through mVISTA, nucleotide diversity, and manual direct sequence analysis. The candidate regions for distinguishing Sanguisorba selected indel or SNP regions. We constructed primers to determine whether the candidate region was amplified and to detect the genetic variant differences of each species. The primers flanking the five variable regions were designed using the Primer-BLAST tool (https:/ / www.ncbi.nlm.nih.gov/tools/primer-blast/ accessed on 15 June 2021). The specificity of these markers was confirmed using PCR amplification with $20 \mathrm{ng}$ of genomic DNA extracted from the samples of five Sanguisorba species and one variety (S. officinalis and S. officinalis var. longifolia, S. hakusanensis, S. stipulata, and S. tenuifolia) in a $20 \mu \mathrm{L}$ PCR mixture (Solg ${ }^{\mathrm{TM}} 2 \times$ Taq PCR smart mix 1, Solgent, Daejeon, Korea) with 10 pmol of each of the matK (primer name: S_matK), rbcL (S_rbcL), matK-rps16 (MR16), $y c f 1$ (Y1-1, Y1-2), and ycf3 intron (Y3) primers. The reaction was carried out on a ProFlex PCR system (Applied Biosystems, Waltham, MA, USA) with the following amplification parameters: initial denaturation at $95^{\circ} \mathrm{C}$ for $2 \mathrm{~min}$; 35 cycles at $95^{\circ} \mathrm{C}$ for $40 \mathrm{~s}, 58-62{ }^{\circ} \mathrm{C}$ for $40 \mathrm{~s}, 72{ }^{\circ} \mathrm{C}$ for $50 \mathrm{~s}$, and a final extension at $72{ }^{\circ} \mathrm{C}$ for $5 \mathrm{~min}$. The PCR products were separated on a $2 \%$ agarose gel for $40 \mathrm{~min}$ at $150 \mathrm{~V}$. Each PCR product was isolated using a gel extraction kit (Qiagen), subcloned into a pGEM-T Easy vector (Promega, Madison, WI, USA), and sequenced using a DNA sequence analyzer (ABI 3730, Applied Biosystems Inc., Foster City, CA, USA). The Sanguisorba accessions used are listed in Table S7. The primer sequences of S_matK, S_rbcL, MR16, Y1-1, Y1-2, and Y3 are listed in Table S9.

\subsection{Phylogenetic Analysis}

A total of $11 \mathrm{cp}$ genomes, nine from Sanguisorbinae along with Agrimonia pilosa and Hagenia abyssinica as outgroups, were used for phylogenetic analysis. Of these, eight cp genome sequences were downloaded from the NCBI GenBank database (Table S10). We used two matrices composed of 77 conserved protein-coding genes (CDSs). Using MAFFT ver. 7.388 [118], the CDS sets were aligned. Each aligned gene was extracted using the Geneious software (https:/ / www.geneious.com, accessed on 20 March 2021), and the genes were arranged alphabetically. The concatenated gene dataset was created using the Geneious software and the CDS dataset. The alignment datasets were filtered to remove ambiguously aligned regions using Gblocks ver. 5 [119]. The best-fitting model of nucleotide substitutions was determined using the Akaike information criterion in jModelTest V2.1.10 [120] (Table S11), and the GTR + I + G model was chosen for ML 
analysis. The GTR + G model was selected for analyzing the BI. The maximum parsimony (MP) analysis was conducted using the PAUP v4.0b10 [121]. The MP searches included 1000 random addition replicates and TBR branch swapping with the MulTrees option. The ML analysis was performed using RaxML v. 8.0 .5 [122] with 1000 bootstrap replicates. The BI analysis was carried out using MrBayes 3.2.2 [123], with two independent runs of four simultaneous chains, executed for 5,000,000 generations using the Markov chain Monte Carlo algorithm. Trees were sampled every 5000 generations, and the first $25 \%$ were discarded as burn-in. The trees were determined from a 50\% majority-rule consensus to estimate the posterior probabilities. The reconstructed trees were visualized using Figtree V.1.4.2 [124].

\section{Conclusions}

This study comprehensively analyzed the floral micromorphological and palynological characteristics and cp genome sequences of the selected species of Sanguisorba. Although the floral micromorphology in all examined species of Sanguisorba was similar, the outer sepal waxes and characteristics in the hypanthium had diagnostic values. The palynological data were constant. However, only S. hakusanensis had tricolporate pollen grains, whereas the other species had hexacolporate pollens. We observed, for the first time, the absence of orbicules in this genus, and this might be a synapomorphic characteristic of the genus Sanguisorba.

Furthermore, genetic variant hotspots were used to develop new DNA barcodes for efficient and rapid species identification. The cp of Sanguisorba is well conserved. However, we identified the varied genetic diversity and selective pressure for $p s b \mathrm{~K}$ in six Sanguisorba cp genomes. We successfully established the phylogenetic relationships among Sanguisorba using the whole cp genome sequences and coding sequences. We successfully conducted a comprehensive study of the morphological, micromorphological, pollenological, and genomic characteristics and marker development of the four hard-to-distinguish species of Sanguisorba. This study provides useful information on Sanguisorba species and a basis for further in-depth research into this plant of medicinal value.

Supplementary Materials: The following are available online at https: / www.mdpi.com/article / 10.3390/genes12111764/s1, Figure S1: Distribution of paired-end reads mapped onto complete chloroplast genomes of three Sanguisorba species. Figure S2: Circular gene map of chloroplast genomes from Sanguisorba. Figure S3: Codon frequencies and RSCU values for six Sanguisorba and one Bencomia chloroplast genomes. Figure S4: Codon distributions of protein-coding genes in Sanguisorba and Bencomia chloroplast genomes. Figure S5: Comparison of complete cp genomes of six Sanguisorba and one Bencomia using the MAUVE algorithm. Figure S6: Comparison of the LSC, IR, and SSC junction positions among Sanguisorba and Bencomia chloroplast genomes. Figure S7: Ka and Ks values for Sanguisorba chloroplast genomes. Figure S8: Ka/Ks values for ATP synthase and Ribosomal proteins related genes in Sanguisorba chloroplast genomes. Figure S9: Schematic representation of indel markers for Sanguisorba species. Figure S10: ITS DNA barcode sequences alignment images for Sanguisorba species. Figure S11: New DNA barcode sequences alignment images for Sanguisorba species. Figure S12: Phylogenetic tree based on 77 CDS from six Sanguisorba using Bayesian posterior probabilities (PP) and maximum likelihood bootstraps (ML). Table S1: Raw and trimmed read data. Table S2: Genome assembly information for three Sanguisorba chloroplast genomes. Table S3: PCR-based sequence validation of chloroplast junctions. Table S4: Genes in the chloroplast genomes of Sanguisorba species. Table S5: Genic introns in S. officinalis, $S$. stipulata, S. hakusanensis chloroplast genomes. Table S6: Genic introns in S. tenuifolia, S. sitchensis, S. filiformis chloroplast genomes. Table S7: Voucher specimen information for floral micromorphology, palynology, and chloroplast genomes, DNA barcode analysis used in this study. Table S8: Primers used in this study for chloroplast junction validation. Table S9: Primer information for DNA barcodes. Table S10: Chloroplast genomes from NCBI used for phylogenetic analysis. Table S11: Best-fitting substitution models selection using jModelTest in CDS sets.

Author Contributions: I.P. and J.S. designed the experimental framework and drafted and revised the manuscript; J.S., S.Y., G.C. and B.M. collected and identified the plant materials; J.S. performed 
microscopic analysis; I.P. performed molecular experiments and performed genome analysis; I.P., J.S. and B.M. revised the manuscript. All authors have read and agreed to the published version of the manuscript.

Funding: This research was funded by a grant from the Development of Sustainable Application for Standard Herbal Resources (KSN2013320) from the Korea Institute of Oriental Medicine (KIOM), Republic of Korea.

Institutional Review Board Statement: Not applicable.

Informed Consent Statement: Not applicable.

Data Availability Statement: The data supporting the findings of this study are available within the article and Table 1.

Conflicts of Interest: The authors declare no conflict of interest.

\section{References}

1. Schulze-Menz, G.K. Rosaceae. In Engler's Syllabus der Pflanzenfamilien II, 12th ed.; Melchior, H., Ed.; Gebrüder Borntraeger: Berlin, Germany, 1964; pp. 209-218.

2. Nordborg, G. Sanguisorba L. Sarcopoterium Spach, and Bencomia Webb et Berth. delimitation and subdivision of the genera. Opera Bot. 1966, 11, 1-103.

3. Mabberley, D.J. The Plant-Book: A Portable Dictionary of the Vascular Plants; Cambridge University Press: New York, NY, USA, 1997.

4. Li, C.L.; Ikeda, H.; Ohba, H. Sanguisorba L. In Flora of China; Wu, Z.Y., Raven, P.H., Eds.; Science Press: Beijing, China; Missouri Botanical Garden Press: St. Louis, MO, USA, 2003; pp. 384-387.

5. The International Plant Names Index and World Checklist of Selected Plant Families. 2021. Available online: http://www.ipni.org and http:/ / apps.kew.org/wcsp/ (accessed on 4 July 2021).

6. Lee, J.; Lee, B.Y.; Kim, Y.S. A taxonomic study of Korean taxa of the Rosaceae genus Sanguisorba. Korean J. Plant Taxon. 2000, 30, 269-285. [CrossRef]

7. Naruhashi, N. Sanguisorba L. In Flora of Japan IIb. Angiospermae Dicotyledoneae Archichlamydeae (b); Iwatsuki, K., Boufford, D.E., Ohba, H., Eds.; Kodansha: Tokyo, Japan, 2001; pp. 180-185.

8. Lee, B.Y. Sanguisorba L. In The Genera of Vascular Plants of Korea; Flora of Korean Editorial Committee, Ed.; Hongreung Publishing Co.: Seoul, Korea, 2018; pp. 731-733.

9. Chinese Pharmacopoeia Commission. Pharmacopoeia of the People's Republic of China; Medical Science and Technology Press: Beijing, China, 2015.

10. Korea Food and Drug Administration. The Korean Herbal Pharmacopoeia, 4th ed.; The KFDA Notification: Seoul, Korea, 2020.

11. Korea Institute of Oriental Medicine [KIOM]. Defining Dictionary for Medicinal Herbs. Available online: http://boncho.kiom.re. $\mathrm{kr} /$ codex (accessed on 4 July 2021).

12. Tu, J.; Li, Q.; Zhou, B. The Tannins from Sanguisorba officinalis L. (Rosaceae): A systematic study on the metabolites of rats based on HPLC-LTQ-Orbitrap MS2 analysis. Molecules 2021, 26, 4053. [CrossRef] [PubMed]

13. Gawron-Gzella, A.; Witkowska-Banaszczak, E.; Bylka, W.; Dudek-Makuch, M.; Odwrot, A.; Skrodzka, N. Chemical composition, antioxidant and antimicrobial activities of Sanguisorba officinalis L. extracts. Pharm. Chem. J. 2016, 50, 244-249. [CrossRef]

14. Chen, X.; Li, B.G.; Gao, Y.; Ji, J.X.; Wu, Z.L.; Chen, S. Saponins from Sanguisorba officinalis improve hematopoiesis by promoting survival through FAK and Erk1/2 activation and modulating cytokine production in bone marrow. Front. Pharmacol. 2017, 8, 130. [CrossRef]

15. Jang, E.; Inn, K.S.; Jang, Y.P.; Lee, K.T.; Lee, J.H. Phytotherapeutic activities of Sanguisorba officinalis and its chemical constituents: A review. Am. J. Chin. Med. 2018, 46, 299-318. [CrossRef]

16. Su, X.D.; Guo, R.H.; Yang, S.Y.; Kim, Y.H.; Kim, Y.R. Anti-bacterial effects of components from Sanguisorba officinalis L. on Vibrio vulnificus and their soluble epoxide hydrolase inhibitory activity. Nat. Prod. Res. 2019, 33, 3445-3449. [CrossRef]

17. Chung, K.-S.; Elisens, W.J.; Skvarla, J.J. Pollen morphology and its phylogenetic significance in tribe Sanguisorbeae (Rosaceae). Plant Syst. Evol. 2010, 285, 139-148. [CrossRef]

18. Lee, S.T.; Heo, K.I.; Cho, J.H.; Lee, C.H.; Chen, W.; Kim, S.C. New insights into pollen morphology and its implications in the phylogeny of Sanguisorba L. (Rosaceae; Sanguisorbeae). Plant Syst. Evol. 2011, 291, 227-242. [CrossRef]

19. Wang, J.R.; Wang, X.; Su, N.; Li, Q.J.; Zhang, X.H.; Ma, Y.P.; Zhao, L.; Toni, J.F.G.; De Craene, L.R. Floral morphology and morphogenesis in Sanguisorba (Rosaceae): Flower diversification despite petal reduction and spatial constraints. Bot. J. Linn. Soc. 2020, 193, 47-63. [CrossRef]

20. Çildir, H.; Kahraman, A.; Dogan, M. Petal and sepal epidermal micromorphology of six Lathyrus taxa (Fabaceae) and their systematic value. Not. Bot. Horti Agrobot. Cluj-Napoca 2012, 40, 35-41. [CrossRef]

21. Song, J.H.; Hong, S.P. A study on the petal micromorphological characteristics of the tribe Sorbarieae (Rosaceae). Korean J. Plant Res. 2016, 29, 376-384. [CrossRef] 
22. Song, J.H.; Roh, H.S.; Hong, S.P. Petal micromorphology and its systematic implications in Rosaceae tribe Spiraeeae. Brittonia 2020, 72, 111-122. [CrossRef]

23. Park, I.; Yang, S.; Song, J.H.; Moon, B.C. Dissection for floral micromorphology and plastid genome of valuable medicinal borages Arnebia and Lithospermum (Boraginaceae). Front. Plant Sci. 2020, 11, 606463. [CrossRef]

24. Wrońska-Pilarek, D.; Jagodziński, A.M. Systematic importance of pollen morphological features of selected species from the genus Rosa (Rosaceae). Plant Syst. Evol. 2011, 295, 55-72. [CrossRef]

25. Xiong, X.H.; Zhou, X.M.; Li, M.; Xu, B.; Deng, H.N.; Yu, Q.; Gao, X.F. Pollen morphology in Rubus (Rosaceae) and its taxonomic implications. Plant Syst. Evol. 2019, 305, 705-716. [CrossRef]

26. Lechowicz, K.; Wrońska-Pilarek, D.; Bocianowski, J.; Maliński, T. Pollen morphology of Polish species from the genus Rubus L. (Rosaceae) and its systematic importance. PLoS ONE 2020, 15, e0221607. [CrossRef]

27. Reitsma, T. Pollen morphology of some European Rosaceae. Acta Bot. Neerl. 1966, 15, 290-307. [CrossRef]

28. Eide, F. Key for northwest European Rosaceae pollen. Grana 1981, 20, 101-118. [CrossRef]

29. Hebda, R.J.; Chinnappa, C.C. Studies on pollen morphology of Rosaceae. Acta Bot. Gallica 1994, 141, 183-193. [CrossRef]

30. Zhou, L.H.; Wei, Z.X.; Wu, Z.Y. Pollen morphology of Maloideae of China (Rosaceae). Acta Bot. Yunnan. 2000, $22,47-52$.

31. Song, J.H.; Moon, H.K.; Hong, S.P. Pollen morphology of the tribe Sorbarieae (Rosaceae). Plant Syst. Evol. 2016, $302,853-869$. [CrossRef]

32. Song, J.H.; Moon, H.K.; Oak, M.K.; Hong, S.P. Phylogenetic evaluation of pollen and orbicule morphology in Rosaceae tribe Neillieae (subfamily Amygdaloideae). Bot. J. Linn. Soc. 2017, 183, 439-453. [CrossRef]

33. Song, J.H.; Oak, M.K.; Roh, H.S.; Hong, S.P. Morphology of pollen and orbicules in the tribe Spiraeeae (Rosaceae) and its systematic implications. Grana 2017, 56, 351-367. [CrossRef]

34. Wicke, S.; Schneeweiss, G.M.; Depamphilis, C.W.; Muller, K.F.; Quandt, D. The evolution of the plastid chromosome in land plants: Gene content, gene order, gene function. Plant Mol. Biol. 2011, 76, 273-297. [CrossRef] [PubMed]

35. Bock, R.; Knoop, V. Genomics of Chloroplasts and Mitochondria; Springer Science \& Business Media: Berlin, Germany, 2012.

36. Daniell, H.; Lin, C.S.; Yu, M.; Chang, W.J. Chloroplast genomes: Diversity, evolution, and applications in genetic engineering. Genome Biol. 2016, 17, 134. [CrossRef]

37. Dong, W.P.; Liu, J.; Yu, J.; Wang, L.; Zhou, S.L. Highly variable chloroplast markers for evaluating plant phylogeny at low taxonomic levels and for DNA barcoding. PLoS ONE 2012, 7, e35071.

38. Song, Y.; Dong, W.P.; Liu, B.; Xu, C.; Yao, X.; Gao, J.; Corlett, R.T. Comparative analysis of complete chloroplast genome sequences of two tropical trees Machilus yunnanensis and Machilus balansae in the family Lauraceae. Front. Plant Sci. 2015, 6, 662. [CrossRef]

39. Park, I.; Yang, S.; Kim, W.J.; Noh, P.; Lee, H.O.; Moon, B.C. The complete chloroplast genomes of six Ipomoea species and indel marker development for the discrimination of authentic Pharbitidis Semen (Seeds of I. nil or I. purpurea). Front. Plant Sci. 2018, 9 , 965. [CrossRef]

40. Kim, K.; Lee, S.C.; Lee, J.; Lee, H.O.; Joh, H.J.; Kim, N.H.; Park, H.S.; Yang, T.J. Comprehensive survey of genetic diversity in chloroplast genomes and 45S nrDNAs within Panax ginseng species. PLoS ONE 2015, 10, e0117159. [CrossRef]

41. Park, I.; Kim, W.J.; Yang, S.; Yeo, S.M.; Li, H.; Moon, B.C. The complete chloroplast genome sequence of Aconitum coreanum and Aconitum carmichaelii and comparative analysis with other Aconitum species. PLoS ONE 2017, 12, e0184257.

42. Park, I.; Yang, S.; Kim, W.J.; Noh, P.; Lee, H.O.; Moon, B.C. Complete chloroplast genome of Sanguisorba x tenuifolia Fisch ex Link. Mitochondrial DNA Part B 2018, 3, 909-910. [CrossRef]

43. Meng, X.X.; Xian, Y.F.; Xiang, L.; Zhang, D.; Shi, Y.H.; Wu, M.L.; Dong, G.Q.; Ip, S.P.; Lin, Z.X.; Wu, L.; et al. Complete chloroplast genomes from Sanguisorba: Identity and variation among four species. Molecules 2018, 23, 2137. [CrossRef]

44. Costa, V.B.S.; Pimentel, R.M.M.; Chagas, M.G.S.; Alves, G.D.; Castro, C.C. Petal micromorphology and its relationship to pollination. Plant Biol. 2017, 19, 115-122. [CrossRef]

45. Barthlott, W. Epicuticular wax ultrastructure and systematics. In Caryophyllales: Evolution and Systematics; Behnke, H.D., Mabry, T.J., Eds.; Springer: Berlin, Germany, 1994; pp. 75-86.

46. Barthlott, W.; Neinhuis, C.; Cutler, D.; Ditsch, F.; Meusel, I.; Theisen, I. Classification and terminology of plant epicuticular waxes. Bot. J. Linn. Soc. 1998, 126, 237-260. [CrossRef]

47. Barthlott, W.; Theisen, I.; Borsch, T.; Neinhuis, C. Epicuticular waxes and vascular plant systematics: Integrating micromorphological and chemical data. In Deep Morphology: Toward a Renaissance of Morphology in Plant Systematics; Stuessy, T.F., Mayer, V., Hörandl, E., Eds.; ARG Gantner Verlag: Ruggell, Germany, 2003; pp. 189-206.

48. Wissemann, V. Epicuticular wax morphology and the taxonomy of Rosa (section Caninae, subsection Rubiginosae). Plant Syst. Evol. 2000, 221, 107-112. [CrossRef]

49. Jeffree, C.E. The fine structure of the plant cuticle. In Biology of the Plant Cuticle. Annual Plant Reviews; Riederer, M., Müller, C., Eds.; Blackwell: Des Moines, IA, USA, 2006; Volume 23, pp. 11-125.

50. Tomaszewski, D.; Zieliński, J. Epicuticular wax structures on stems and comparison between stems and leaves-A survey. Flora-Morphol. Distrib. Funct. Ecol. Plants 2014, 209, 215-232. [CrossRef]

51. Tomaszewski, D.; Byalt, A.; Gawlak, M. Leaf and stem epicuticular wax structures in Lonicera species (Caprifoliaceae). Nord. J. Bot. 2019, 37, e02210. [CrossRef]

52. Juhari, A.A.A.; Talip, N.; Che, C.N.A.; Amri, S.K.A.R.; Mansur, N.S. Taxonomic significance of petal and sepal micromorphological characteristics in some Justicia nees (Acanthaceae) species in Peninsular Malaysia. Trop. Life Sci. Res. 2019, 30, 51-69. [CrossRef] 
53. Besi, E.E.; Eee, L.Y.; Eng, K.H.; Ching, T.M.; Nulit, R.; Go, R. Floral-surface micromorphology of Corybas selangorensis J. Dransf. \& G. Sm. and Corybas holttumii J. Dransf. \& G. Sm. (Orchidaceae). J. Orchid Soc. India 2019, 33, 47-56.

54. Besi, E.E.; Nikong, D.; Mustafa, M.; Yong, C.S.Y.; Go, R. Taxonomic placement of four confusable Crepidium species (Orchidaceae, Malaxidinae) based on macro-and micro-morphological analyses, including a note on two new records to Peninsular Malaysia. Phytotaxa 2020, 454, 31-44. [CrossRef]

55. Besi, E.E.; Jia, L.S.; Mustafa, M.; Yong, C.S.; Go, R. Comparative floral surface micromorphology helps to discriminate between species of Paphiopedilum (Orchidaceae: Cypripedioideae) from Peninsular Malaysia. Lankesteriana 2021, 21, 17-31.

56. Koch, K.; Barthlott, W. Plant epicuticular waxes: Chemistry, form, self-assembly and function. Nat. Prod. Commun. 2006, 1, 1067-1072. [CrossRef]

57. Schreiber, L. Characterisation of polar paths of transport in plant cuticles. In Biology of the Plant Cuticle. Annual Plant Reviews; Riederer, M., Müller, C., Eds.; Blackwell: Des Moines, IA, USA, 2006; Volume 23, pp. 280-289.

58. Haworth, M.; McElwain, J. Hot, dry, wet, cold or toxic? Revisiting the ecological significance of leaf and cuticular micromorphology. Palaeogeogr. Palaeoclimatol. Palaeoecol. 2008, 262, 79-90. [CrossRef]

59. Whitehead, D.R. Wind pollination in the angiosperms: Evolutionary and environmental considerations. Evolution 1969, $23,28-35$. [CrossRef]

60. Niklas, K.J. The aerodynamics of wind pollination. Bot. Rev. 1985, 51, 328-386. [CrossRef]

61. Hebda, R.J.; Chinnappa, C.C. Studies on pollen morphology of Rosaceae in Canada. Rev. Palaeobot. Palynol. 1990, 64, 103-108. [CrossRef]

62. Zhou, L.H.; Wei, Z.X.; Wu, Z.Y. Pollen morphology of Prunoideae of China (Rosaceae). Acta Bot. Yunnan. 1999, $21,207-211$.

63. Wang, F.X.; Qian, N.F.; Zhang, Y.L.; Yang, H.Q. Pollen Flora of China; Science Press: Beijing, China, 1997.

64. Lee, F.; Wan, P.; Gao, S.; Ding, Y.; Zhou, F. Pollen morphology identification of five species of medicinal Sanguisorba with electron microscope. China J. Chin. Mater. Med. 1999, 24, 715-717.

65. Xu, Q.H. Pollen Morphology of Common Cultivated Plants in China-A Reference for Looking for Human Traces in the Stratum; Science Press: Beijing, China, 2005.

66. Punt, W.; Hoen, P.P.; Blackmore, S.; Nilsson, S.; Le Thomas, A. Glossary of pollen and spore terminology. Rev. Palaeobot. Palynol. 2007, 143, 1-81. [CrossRef]

67. Agashe, S.N.; Caulton, E. Pollen and Spores: Applications with Special Emphasis on Aerobiology and Allergy; Science Publishers: Grafton County, NH, USA, 2009.

68. El-Ghazaly, G.; Nilsson, S. Development of tapetum and orbicules of Catharanthus roseus (Apocynaceae). In Pollen Spores: Patterns of Diversity; Balckmore, S., Barnes, S.H., Eds.; Clarendon Press: Oxford, UK, 1991; pp. 317-329.

69. Huysmans, S.; El-Ghazaly, G.; Smets, E. Orbicules: Still a well hidden secret of the anther. In Plant Systematics for the 21st Century, Wenner-Gren International Series; Nordenstam, B., El-Ghazaly, G., Kassas, M., Eds.; Portland Press: London, UK, 2000; Volume 77, pp. 201-212.

70. Galati, B.G. Ubisch bodies in angiosperms. In Advances in Plant Reproductive Biology; Chauhann, M.R., Pandey, A.K., Eds.; Narendra Publishing House: Delhi, India, 2003; pp. 1-20.

71. Moon, H.K. The phylogenetic potential of orbicules in angiosperms. Korean J. Plant Taxon. 2018, 48, 9-23. [CrossRef]

72. Gichira, A.W.; Li, Z.; Saina, J.K.; Long, Z.; Hu, G.; Gituru, R.W.; Wang, Q.; Chen, J. The complete chloroplast genome sequence of an endemic monotypic genus Hagenia (Rosaceae): Structural comparative analysis, gene content and microsatellite detection. PeerJ 2017, 5, e2846. [CrossRef] [PubMed]

73. Heo, K.I.; Park, J.; Xi, H.; Min, J. The complete chloroplast genome of Agrimonia pilosa Ledeb. isolated in Korea (Rosaceae): Investigation of intraspecific variations on its chloroplast genomes. Mitochondrial DNA Part B 2020, 5, 2264-2266. [CrossRef] [PubMed]

74. Wang, Y.; Zhan, D.F.; Jia, X.; Mei, W.L.; Dai, H.F.; Chen, X.T.; Peng, S.Q. Complete chloroplast genome sequence of Aquilaria sinensis (Lour.) Gilg and evolution analysis within the Malvales order. Front. Plant Sci. 2016, 7, 280. [CrossRef]

75. Yi, S.; Li, Y.; Wang, W. Selection shapes the patterns of codon usage in three closely related species of genus Misgurnus. Genomics 2018, 110, 134-142. [CrossRef]

76. Ivanova, Z.; Sablok, G.; Daskalova, E.; Zahmanova, G.; Apostolova, E.; Yahubyan, G.; Baev, V. Chloroplast genome analysis of resurrection tertiary relict Haberlea rhodopensis highlights genes important for desiccation stress response. Front. Plant Sci. 2017, 8, 204. [CrossRef]

77. Zuo, L.H.; Shang, A.Q.; Zhang, S.; Yu, X.Y.; Ren, Y.C.; Yang, M.S.; Wang, J.M. The first complete chloroplast genome sequences of Ulmus species by de novo sequencing: Genome comparative and taxonomic position analysis. PLoS ONE 2017, 12, e0171264. [CrossRef]

78. Delannoy, E.; Fujii, S.; Colas des Francs-Small, C.; Brundrett, M.; Small, I. Rampant gene loss in the underground orchid Rhizanthella gardneri highlights evolutionary constraints on plastid genomes. Mol. Biol. Evol. 2011, 28, 2077-2086. [CrossRef]

79. Wolfe, K.H.; Morden, C.W.; Palmer, J.D. Function and evolution of a minimal plastid genome from a nonphotosynthetic parasitic plant. Proc. Natl. Acad. Sci. USA 1992, 89, 10648-10652. [CrossRef]

80. Guo, Y.Y.; Yang, J.X.; Li, H.K.; Zhao, H.S. Chloroplast genomes of two species of Cypripedium: Expanded genome size and proliferation of AT-biased repeat sequences. Front. Plant Sci. 2021, 12, 142. [CrossRef] [PubMed] 
81. Lahaye, R.; Van der Bank, M.; Bogarin, D.; Warner, J.; Pupulin, F.; Gigot, G.; Maurin, O.; Duthoit, S.; Barraclough, T.G.; Savolainen, V. DNA barcoding the floras of biodiversity hotspots. Proc. Natl. Acad. Sci. USA 2008, 105, 2923-2928. [CrossRef]

82. Dong, W.L.; Wang, R.N.; Zhang, N.Y.; Fan, W.B.; Fang, M.F.; Li, Z.H. Molecular evolution of chloroplast genomes of Orchid species: Insights into phylogenetic relationship and adaptive evolution. Int. J. Mol. Sci. 2018, 19, 716. [CrossRef]

83. Liu, L.X.; Wang, Y.W.; He, P.Z.; Li, P.; Lee, J.; Soltis, D.E.; Fu, C.X. Chloroplast genome analyses and genomic resource development for epilithic sister genera Oresitrophe and Mukdenia (Saxifragaceae), using genome skimming data. BMC Genom. 2018, 19, 235. [CrossRef]

84. Smidt, E.D.; Paez, M.Z.; Vieira, L.N.; Viruel, J.; de Baura, V.A.; Balsanelli, E.; de Souza, E.M.; Chase, M.W. Characterization of sequence variability hotspots in Cranichideae plastomes (Orchidaceae, Orchidoideae). PLoS ONE 2020, 15, e0227991.

85. Raubeson, L.A.; Peery, R.; Chumley, T.W.; Dziubek, C.; Fourcade, H.M.; Boore, J.L.; Jansen, R.K. Comparative chloroplast genomics: Analyses including new sequences from the angiosperms Nuphar advena and Ranunculus macranthus. BMC Genom. 2007, 8, 174. [CrossRef]

86. Lin, T.P.; Chuang, W.J.; Huang, S.S.F.; Hwang, S.Y. Evidence for the existence of some dissociation in an otherwise strong linkage disequilibrium between mitochondrial and chloroplastic genomes in Cyclobalanopsis glauca. Mol. Ecol. 2003, 12, 2661-2668. [CrossRef]

87. Parks, M.; Cronn, R.; Liston, A. Increasing phylogenetic resolution at low taxonomic levels using massively parallel sequencing of chloroplast genomes. BMC Biol. 2009, 7, 84. [CrossRef]

88. Gao, C.; Deng, Y.; Wang, J. The complete chloroplast genomes of Echinacanthus species (Acanthaceae): Phylogenetic relationships, adaptive evolution, and screening of molecular markers. Front. Plant Sci. 2018, 9, 1989. [CrossRef]

89. Xie, D.F.; Yu, H.X.; Price, M.; Xie, C.; Deng, Y.Q.; Chen, J.P.; Yu, Y.; Zhou, S.D.; He, X.J. Phylogeny of Chinese Allium species in section Daghestanica and adaptive evolution of Allium (Amaryllidaceae, Allioideae) species revealed by the chloroplast complete genome. Front. Plant Sci. 2019, 10, 460. [CrossRef]

90. Li, P.P.; Lou, G.L.; Cai, X.R.; Zhang, B.; Cheng, Y.Q.; Wang, H.W. Comparison of the complete plastomes and the phylogenetic analysis of Paulownia species. Sci. Rep. 2020, 10, 2225. [CrossRef]

91. Wang, R.N.; Milne, R.I.; Du, X.Y.; Liu, J.; Wu, Z.Y. Characteristics and mutational hotspots of plastomes in Debregeasia (Urticaceae). Front. Genet. 2020, 11, 729. [CrossRef]

92. Chen, S.L.; Yao, H.; Han, J.P.; Liu, C.; Song, J.Y.; Shi, L.C.; Zhu, Y.J.; Ma, X.Y.; Gao, T.; Pang, X.H.; et al. Validation of the ITS2 Region as a novel DNA barcode for identifying medicinal plant species. PLoS ONE 2010, 5, e8613. [CrossRef]

93. Selvaraj, D.; Shanmughanandhan, D.; Sarma, R.K.; Joseph, J.C.; Srinivasan, R.V.; Ramalingam, S. DNA barcode ITS effectively distinguishes the medicinal plant Boerhavia diffusa from its adulterants. Genom. Proteom. Bioinform. 2012, 10, 364-367. [CrossRef] [PubMed]

94. Yu, J.; Wu, X.; Liu, C.; Newmaster, S.; Ragupathy, S.; Kress, W.J. Progress in the use of DNA barcodes in the identification and classification of medicinal plants. Ecotox. Environ. Safe. 2021, 208, 111691. [CrossRef]

95. Chung, H.Y.; Won, S.Y.; Kim, Y.K.; Kim, J.S. Development of the chloroplast genome-based InDel markers in Niitaka (Pyrus pyrifolia) and its application. Plant Biotechnol. Rep. 2019, 13, 51-61. [CrossRef]

96. Hechanova, S.L.; Bhattarai, K.; Simon, E.V.; Clave, G.; Karunarathne, P.; Ahn, E.K.; Li, C.P.; Lee, J.S.; Kohli, A.; Hamilton, N.R.S.; et al. Development of a genome-wide InDel marker set for allele discrimination between rice (Oryza sativa) and the other seven AA-genome Oryza species. Sci. Rep. 2021, 11, 8962. [CrossRef]

97. Mishima, M.; Ohmido, N.; Fukui, K.; Yahara, T. Trends in site-number change of rDNA loci during polyploid evolution in Sanguisorba (Rosaceae). Chromosoma 2002, 110, 550-558. [CrossRef]

98. Jansen, R.K.; Cai, Z.; Raubeson, L.A.; Daniell, H.; Depamphilis, C.W.; Leebens-Mack, J.; Muller, K.F.; Guisinger-Bellian, M.; Haberle, R.C.; Hansen, A.K.; et al. Analysis of 81 genes from 64 plastid genomes resolves relationships in angiosperms and identifies genome-scale evolutionary patterns. Proc. Natl. Acad. Sci. USA 2007, 104, 19369-19374. [CrossRef]

99. Wickham, H. ggplot2: Elegant Graphics for Data Analysis; Springer: New York, NY, USA, 2009.

100. Verstraete, B.; Groeninckx, I.; Smets, E.; Huysmans, S. Phylogenetic signal of orbicules at family level: Rubiaceae as case study. Taxon 2011, 60, 742-757. [CrossRef]

101. Allen, G.C.; Flores-Vergara, M.A.; Krasnyanski, S.; Kumar, S.; Thompson, W.F. A modified protocol for rapid DNA isolation from plant tissues using cetyltrimethylammonium bromide. Nat. Protoc. 2006, 1, 2320-2325. [CrossRef]

102. Luo, R.; Liu, B.; Xie, Y.; Li, Z.; Huang, W.; Yuan, J.; He, G.; Chen, Y.; Pan, Q.; Liu, Y.; et al. SOAPdenovo2: An empirically improved memory-efficient short-read de novo assembler. Gigascience 2012, 1, 18. [CrossRef]

103. Delcher, A.L.; Salzberg, S.L.; Phillippy, A.M. Using MUMmer to identify similar regions in large sequence sets. Curr. Protoc. Bioinform. 2003, 10.3.1-10.3.18. [CrossRef]

104. Li, H.; Durbin, R. Fast and accurate long-read alignment with Burrows-Wheeler transform. Bioinformatics 2010, 26, 589-595. [CrossRef]

105. Tillich, M.; Lehwark, P.; Pellizzer, T.; Ulbricht-Jones, E.S.; Fischer, A.; Bock, R.; Greiner, S. GeSeq-Versatile and accurate annotation of organelle genomes. Nucleic Acids Res. 2017, 45, W6-W11. [CrossRef]

106. Carver, T.; Berriman, M.; Tivey, A.; Patel, C.; Bohme, U.; Barrell, B.G.; Parkhill, J.; Rajandream, M.A. Artemis and ACT: Viewing, annotating and comparing sequences stored in a relational database. Bioinformatics 2008, 24, 2672-2676. [CrossRef] 
107. Lowe, T.M.; Eddy, S.R. tRNAscan-SE: A program for improved detection of transfer RNA genes in genomic sequence. Nucleic Acids Res. 1997, 25, 955-964. [CrossRef]

108. Gurusaran, M.; Ravella, D.; Sekar, K. RepEx: Repeat extractor for biological sequences. Genomics 2013, 102, 403-408. [CrossRef]

109. Greiner, S.; Lehwark, P.; Bock, R. OrganellarGenomeDRAW (OGDRAW) version 1.3.1: Expanded toolkit for the graphical visualization of organellar genomes. Nucleic Acids Res. 2019, 47, W59-W64. [CrossRef]

110. Kumar, S.; Stecher, G.; Tamura, K. MEGA7: Molecular evolutionary genetics analysis version 7.0 for bigger datasets. Mol. Biol. Evol. 2016, 33, 1870-1874. [CrossRef]

111. Babicki, S.; Arndt, D.; Marcu, A.; Liang, Y.J.; Grant, J.R.; Maciejewski, A.; Wishart, D.S. Heatmapper: Web-enabled heat mapping for all. Nucleic Acids Res. 2016, 44, W147-W153. [CrossRef]

112. Darling, A.E.; Mau, B.; Perna, N.T. progressiveMauve: Multiple genome alignment with gene gain, loss and rearrangement. PLoS ONE 2010, 5, e11147. [CrossRef]

113. Rozas, J.; Ferrer-Mata, A.; Sanchez-DelBarrio, J.C.; Guirao-Rico, S.; Librado, P.; Ramos-Onsins, S.E.; Sanchez-Gracia, A. DnaSP 6: DNA sequence polymorphism analysis of large data sets. Mol. Biol. Evol. 2017, 34, 3299-3302. [CrossRef]

114. Wang, D.; Zhang, Y.; Zhang, Z.; Zhu, J.; Yu, J. KaKs_Calculator 2.0: A toolkit incorporating gamma-series methods and sliding window strategies. Genom. Proteom. Bioinform. 2010, 8, 77-80. [CrossRef]

115. Kurtz, S.; Choudhuri, J.V.; Ohlebusch, E.; Schleiermacher, C.; Stoye, J.; Giegerich, R. REPuter: The manifold applications of repeat analysis on a genomic scale. Nucleic Acids Res. 2001, 29, 4633-4642. [CrossRef]

116. Beier, S.; Thiel, T.; Munch, T.; Scholz, U.; Mascher, M. MISA-web: A web server for microsatellite prediction. Bioinformatics 2017, 33, 2583-2585. [CrossRef]

117. Benson, G. Tandem repeats finder: A program to analyze DNA sequences. Nucleic Acids Res. 1999, 27, 573-580. [CrossRef]

118. Katoh, K.; Misawa, K.; Kuma, K.I.; Miyata, T. MAFFT: A novel method for rapid multiple sequence alignment based on fast Fourier transform. Nucleic Acids Res. 2002, 30, 3059-3066. [CrossRef]

119. Castresana, J. Selection of conserved blocks from multiple alignments for their use in phylogenetic analysis. Mol. Biol. Evol. 2000, 17, 540-552. [CrossRef]

120. Darriba, D.; Taboada, G.L.; Doallo, R.; Posada, D. jModelTest 2: More models, new heuristics and parallel computing. Nat. Methods 2012, 9, 772. [CrossRef]

121. Swofford, D.L.; Documentation, B. Phylogenetic Analysis Using Parsimony; Illinois Natural History Survey: Champaign, IL, USA, 1989.

122. Stamatakis, A. RAxML version 8: A tool for phylogenetic analysis and post-analysis of large phylogenies. Bioinformatics 2014, 30, 1312-1313. [CrossRef]

123. Ronquist, F.; Teslenko, M.; van der Mark, P.; Ayres, D.L.; Darling, A.; Hohna, S.; Larget, B.; Liu, L.; Suchard, M.A.; Huelsenbeck, J.P. MrBayes 3.2: Efficient Bayesian phylogenetic inference and model choice across a large model space. Syst. Biol. $2012,61,539-542$. [CrossRef]

124. Rambaut, A. FigTree v1. 4. Molecular Evolution, Phylogenetics and Epidemiology. University of Edinburgh, Institute of Evolutionary Biology: Edinburgh, UK, 2012. Available online: http://tree.bio.ed.ac.uk/software/figtree/ (accessed on 4 July 2021). 